UCRL-ID-131166

\title{
Isothermal Fatigue
}

\author{
D. Lesuer \\ C. Syn
}

June 1998

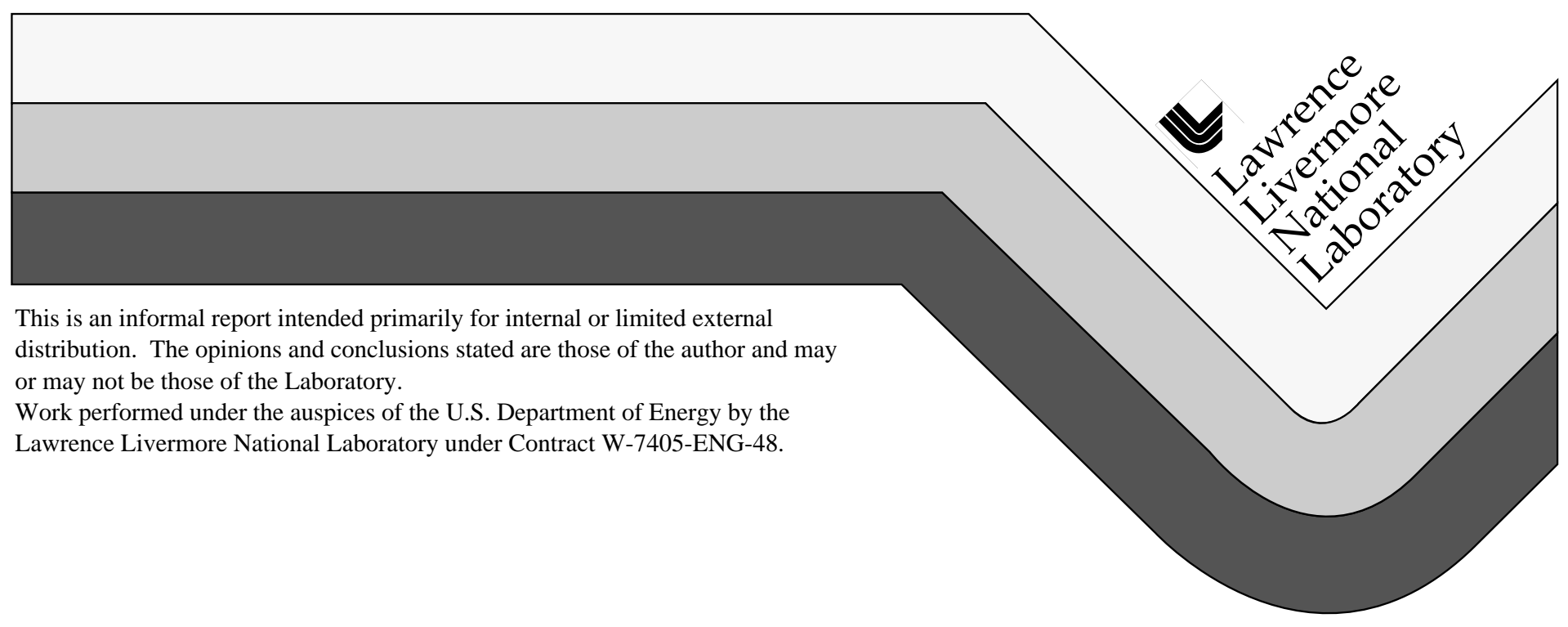




\section{DISCLAIMER}

This document was prepared as an account of work sponsored by an agency of the United States Government. Neither the United States Government nor the University of California nor any of their employees, makes any warranty, express or implied, or assumes any legal liability or responsibility for the accuracy, completeness, or usefulness of any information, apparatus, product, or process disclosed, or represents that its use would not infringe privately owned rights. Reference herein to any specific commercial product, process, or service by trade name, trademark, manufacturer, or otherwise, does not necessarily constitute or imply its endorsement, recommendation, or favoring by the United States Government or the University of California. The views and opinions of authors expressed herein do not necessarily state or reflect those of the United States Government or the University of California, and shall not be used for advertising or product endorsement purposes.

This report has been reproduced directly from the best available copy.

Available to DOE and DOE contractors from the Office of Scientific and Technical Information P.O. Box 62, Oak Ridge, TN 37831

Prices available from (423) 576-8401

Available to the public from the National Technical Information Service

U.S. Department of Commerce 5285 Port Royal Rd. Springfield, VA 22161 
Lightweight Materials for Automotive Applications

CRADA TC-0296-92-B

between General Motors Research and Development Center and

Lawrence Livermore National Laboratory

Topic 3 Metal Matrix Composites

Fatigue Subtask

\title{
Isothermal Fatigue
}

Don Lesuer and Chol Syn

Lawrence Livermore National Laboratory

Livermore, CA 94551

\begin{abstract}
Metal matrix composites consisting of the 339 aluminum casting reinforced with Kaowool have been studied for their high cycle fatigue behavior. This report describes results and data analysis for the 339/Kaowool/15w composite. The project involved testing $130339 /$ Kaowool/15w samples at different temperatures from room temperature to $300^{\circ} \mathrm{C}$. Experiments were conducted on samples that had received different annealing treatments before testing. The defects responsible for fatigue failure were characterized. In the high cycle fatigue regime, the number of cycles to failure was found to vary as a power law function of the stress. Sufficient data were available for failures originating from three different defect / testing temperature combinations to quantify the relationship between defect type, defect size and cycling stress on resulting fatigue life. The three defect type / testing temperature combinations were shot particles at $200^{\circ} \mathrm{C}$, porosity at $200^{\circ} \mathrm{C}$ and shot particles at $300^{\circ} \mathrm{C}$. A new model was proposed to predict the life of samples as a function of stress and defect characteristics (size and type). For the three data sets described above, the model could predict the life of the three different defect / temperature combinations described above to better than half a decade.
\end{abstract}




\section{INTRODUCTION}

The isothermal, high cycle fatigue behavior of two metal matrix composites (339/Kaowool/7 $\mathrm{w}^{1}$ and 339/Kaowool/15w) and the matrix alloy (339 aluminum casting alloy) has been evaluated at room temperature and elevated temperature. Axial fatigue tests were performed. The failure initiation sites were then identified and the microstructural features participating in the fatigue process were analyzed. Most of the work was done on the 339/Kaowool/15w composite. During the project, 130 $339 / \mathrm{Kaowool} / 15 \mathrm{w}$ samples were tested, and, for most of these samples, the fracture surfaces were characterized. Samples were annealed and tested at a number of different temperatures. This report is concerned with the mechanism of fatigue failure at $200^{\circ} \mathrm{C}$ and $300^{\circ} \mathrm{C}$. For most of the samples, the failure origin and defects responsible for fatigue failure could be established. The data was analyzed with the intent of quantifying the relationship between defect type, defect size and cycling stress on the resulting fatigue life.

\section{MATERIALS AND EXPERIMENTAL PROCEDURES}

\section{Materials.}

Work was completed on three different types of 339/Kaowool/15w composite. The materials differ in the cleaning processes used to remove objectionably large particles from the ceramic reinforcement before pre-form fabrication. The reinforcement resulting from these three cleaning processes are referred to as high shot, low shot and Didier cleaned. The high shot material had no cleaning of the reinforcement prior to pre-form fabrication. The low shot material was cleaned by Thermal Ceramics Inc. prior to preform fabrication. The Didier-cleaned material was cleaned by a French firm prior to preform fabrication using a proprietary process.

Work by General Motors (GM) has established that overaging of the matrix can result from annealing the $339 / \mathrm{Kaowool}$ composites at the testing temperatures $\left(200^{\circ} \mathrm{C}\right.$ and $300^{\circ} \mathrm{C}$ ). This matrix overaging can produce significant reductions in fatigue life. Therefore, all data analyzed in this report was on done on material annealed at the testing temperature for 200 hours (time required for $10^{7}$ cycles) prior to fatigue experiments. These annealing treatments overaged the matrix of the composite and thus eliminated the softening of the matrix that occurs with time in a fatigue test as a factor in analysis of fatigue life.

1 This report specifies MMCs according to a system established by the Aluminum Association. This five part system designates the composite by aluminum alloy, reinforcement material, volume percentage reinforcement, reinforcement morphology and matrix alloy temper. 
Disks of the composite were squeeze cast by GM. The castings were then aged for 8 hours at $210^{\circ} \mathrm{C}$ to produce a $\mathrm{T} 5$ temper in the matrix prior to the machining of cylindrical samples. Samples were pre-aged by LLNL at the intended testing temperature for 200 hours. The gage section of all samples was polished by GM or LLNL. For the GMpolished samples, this procedure was completed before the pre-aging treatment. For the LLNL-polished samples, this procedure was completed after the pre-aging treatment. No difference in failure origins or fatigue data was observed between the LLNL- and GM-polished samples. The polishing procedure used by LLNL and the resulting surface finish have been documented in a previous report [1]. An optical micrograph of the 339/Kaowool/15w composite is shown in Fig. 1.

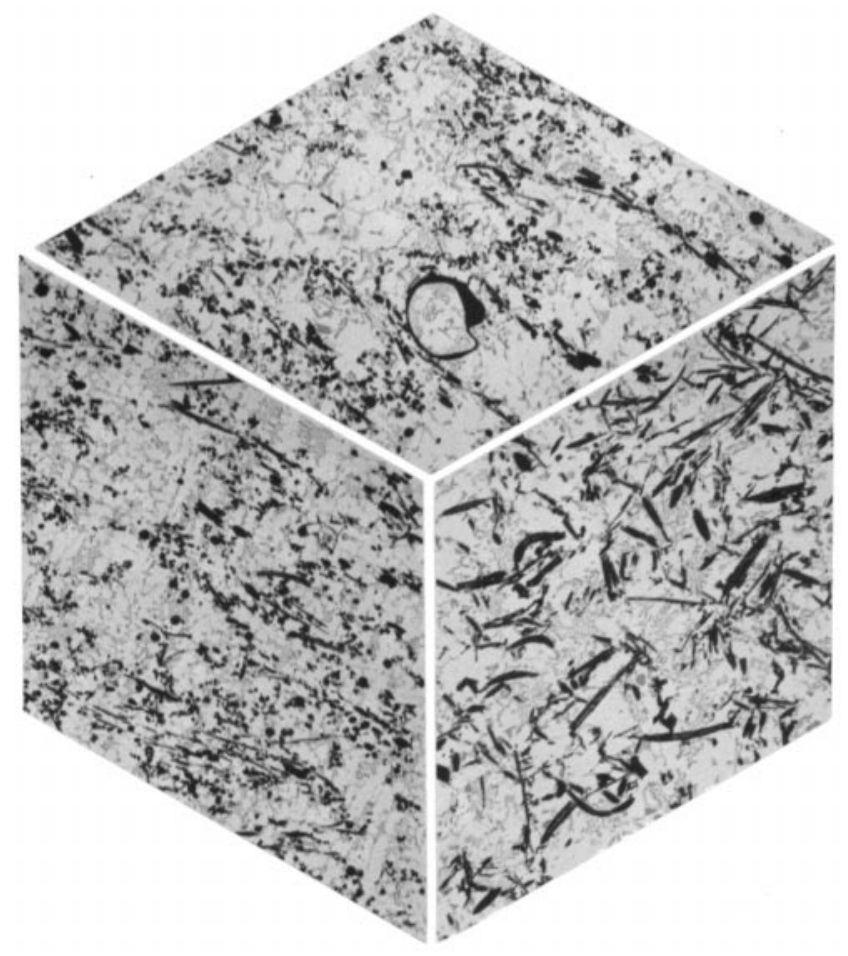

Fig. 1. Optical micrograph of the 339/Kaowool/15w composite.

\section{Testing and fracture surface examination.}

Axial fatigue tests were conducted in air with an MTS servohydraulic system and MTS hydraulic grips containing wedge jaws. All testing was done using fully reverse loading $(R=-1)$ under load control (sinusoidal waveform) with an operating frequency of $20 \mathrm{~Hz}$. Cycling stresses were chosen to provide data primarily in the high cycle fatigue regime (> $10^{5}$ cycles to failure).

Fatigue fractured samples were examined using SEM to locate the fatigue failure initiation site and characterize the flaw that initiated failure. The matching fracture surfaces of each broken sample were coated with a thin layer of $\mathrm{Au}-\mathrm{Pd}$ and photographed at a low magnification (25X to $50 \mathrm{X}$ ) first to locate the origin of the fatigue crack, and then at higher magnifications (up to 5000X) to determine the shape and size of the flaw at the origin. On some samples, X-ray energy dispersive spectrometry 
(EDS) was performed to identify the chemical composition of the flaw at the origin. The relative location of the flaw with respect to the sample surface was also measured and tabulated with other information on the fatigue test and the nature of the crack initiating flaw of each sample.

Most of the fatigue failures initiated at porosity or shot particles. Typical orgins are shown in Figs. 2 and 3 for porosity or shot-initiated failures respectively.

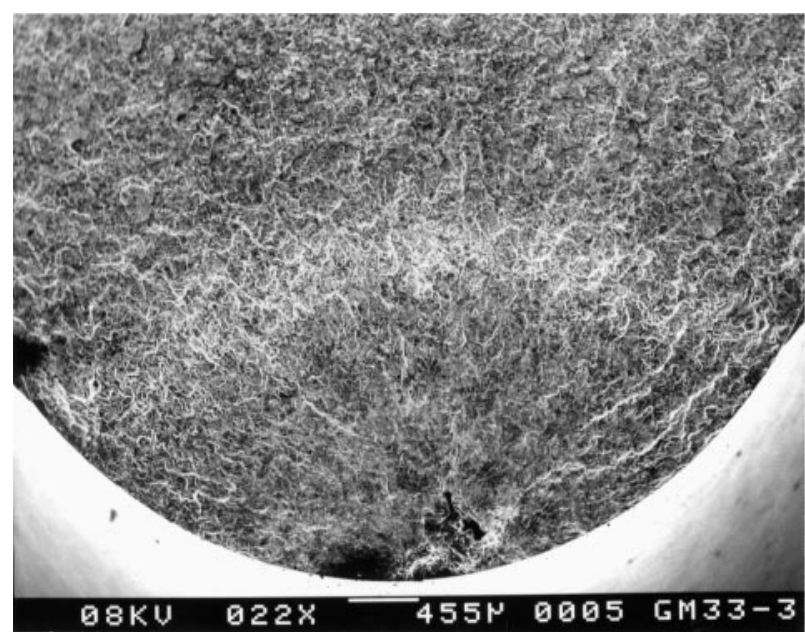

a

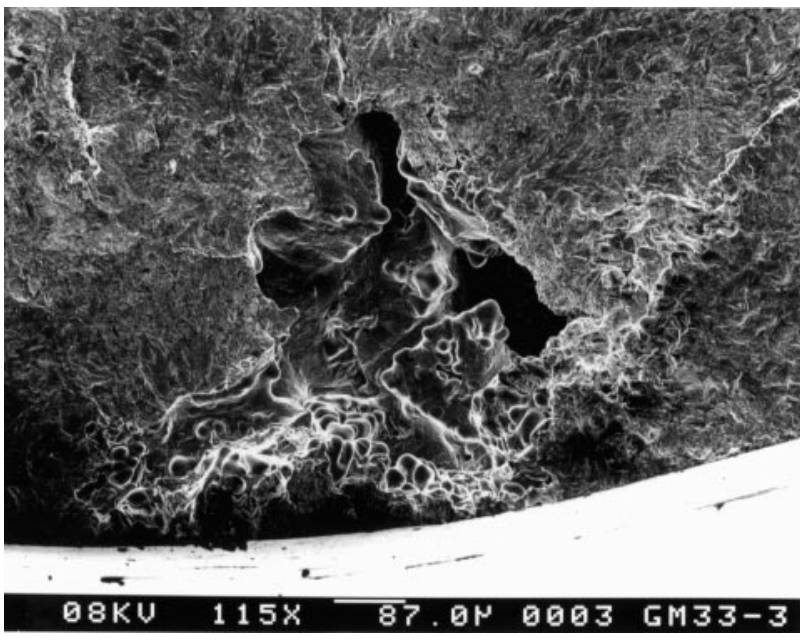

b

Fig. 2. Typical fatigue failure origin resulting from porosity. Sample is the 339 matrix alloy tested at $20^{\circ} \mathrm{C}$. Fracture surface is shown at low (a) and high magnification (b).

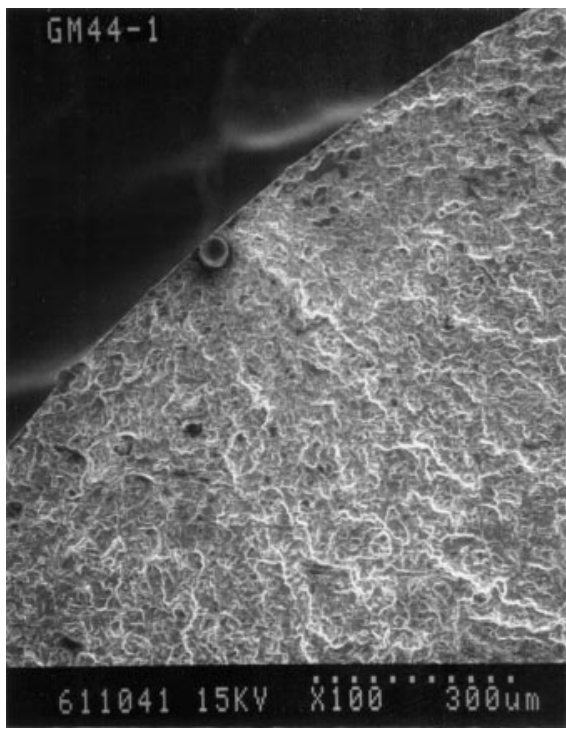

a

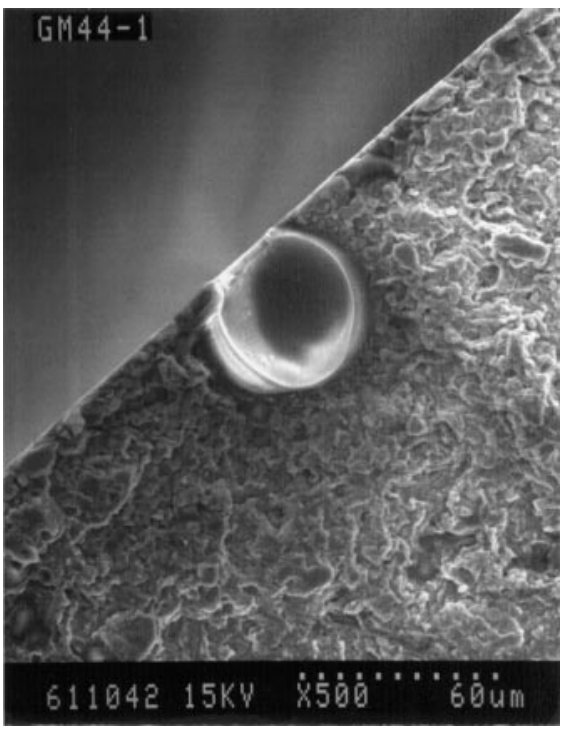

b

Fig. 3. Typical fatigue failure origin resulting from a shot particle. Sample is the $339 / \mathrm{Kaowool} / 7 \mathrm{w}$ composite tested at $300^{\circ} \mathrm{C}$. Fracture surface is shown at low (a) and high magnification (b). 


\section{EXPERIMENTAL RESULTS AND DISCUSSION}

\section{Stress - life behavior.}

All the isothermal fatigue data obtained in this project are given in the Appendix, which includes fatigue test results as well as the characteristics of the defect that initiated the fatigue failure. These initiating defects are characterized by defect type, shape, size (dimensions in two orthogonal directions), location (given as a distance below the surface) and the size of the stable fatigue crack growth zone.

Fatigue data for the 339/Kaowool/15w composite manufactured with high shot, low shot and Didier-cleaned reinforcement are shown in Figs. 4, 5 and 6, respectively. Data for the high shot and low shot material are for tests conducted at $20^{\circ} \mathrm{C}, 200^{\circ} \mathrm{C}$ and $300^{\circ} \mathrm{C}$, while data for the Didier-cleaned material are for tests conducted at $200^{\circ} \mathrm{C}$ and $300^{\circ} \mathrm{C}$ only. Results are plotted as the maximum stress $\left(\sigma_{\max }=\Delta \sigma / 2\right.$, also referred to as $\left.\sigma\right)$ versus number of cycles to failure. All curves in the plots represent the least squares fit of the data to a power law equation using the curve fitting routines in KaleidaGraph (a commercially available data analysis and plotting program). The agreement between the calculated curve and the experimental data is generally very good, which shows that the number of cycles to failure can be represented as a power law function of the stress. This is an important result that will be used in the next section of this report. Figures 4 and 5 show that the $\sigma-\mathrm{N}$ curves at $20^{\circ} \mathrm{C}$ are much flatter (less change in $\sigma$ with increasing number of cycles to failure) than the $\sigma-\mathrm{N}$ curves at $200^{\circ} \mathrm{C}$ in the high shot material and $200^{\circ} \mathrm{C}$ and $300^{\circ} \mathrm{C}$ in the low shot material. This seems to be a real effect. The mechanistic origins of this effect, however, are not understood at this time.

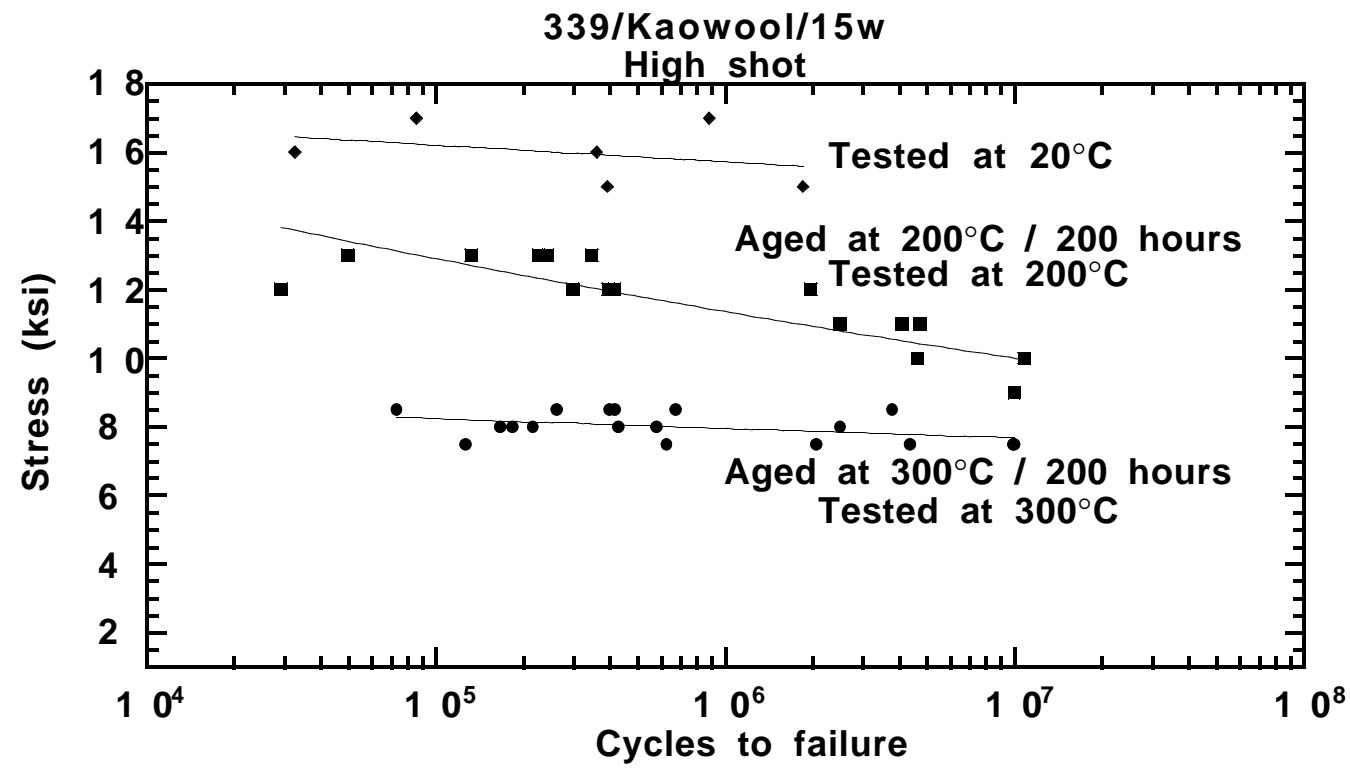

Fig. 4. Stress versus life for the high shot 339/Kaowool/15w composite tested at $20^{\circ} \mathrm{C}, 200^{\circ} \mathrm{C}$ and $300^{\circ} \mathrm{C}$. Samples were pre-annealed at the testing temperature for 200 hours before the fatigue experiments. 


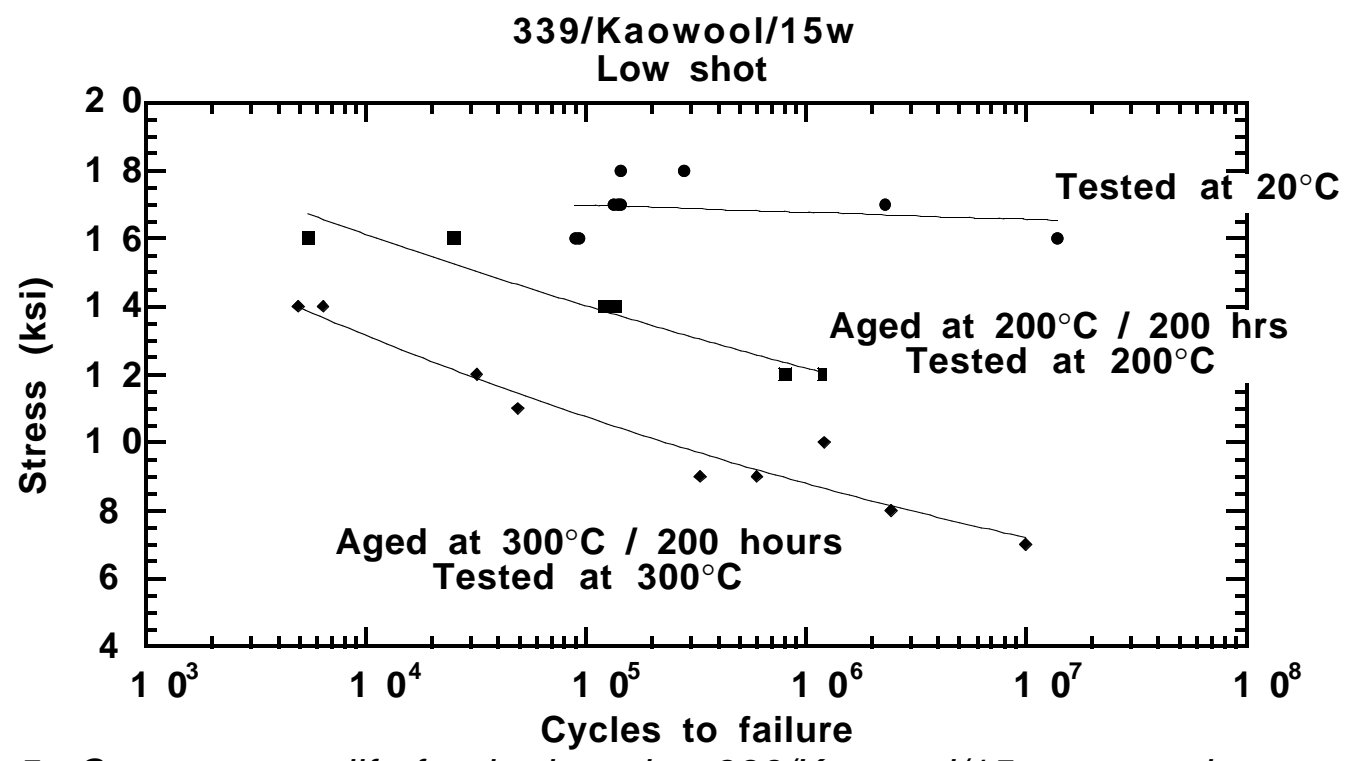

Fig. 5. Stress versus life for the low shot 339/Kaowool/15w composite tested at $20^{\circ} \mathrm{C}, 200^{\circ} \mathrm{C}$ and $300^{\circ} \mathrm{C}$. Samples were pre-annealed at the testing temperature for 200 hours before the fatigue experiments.

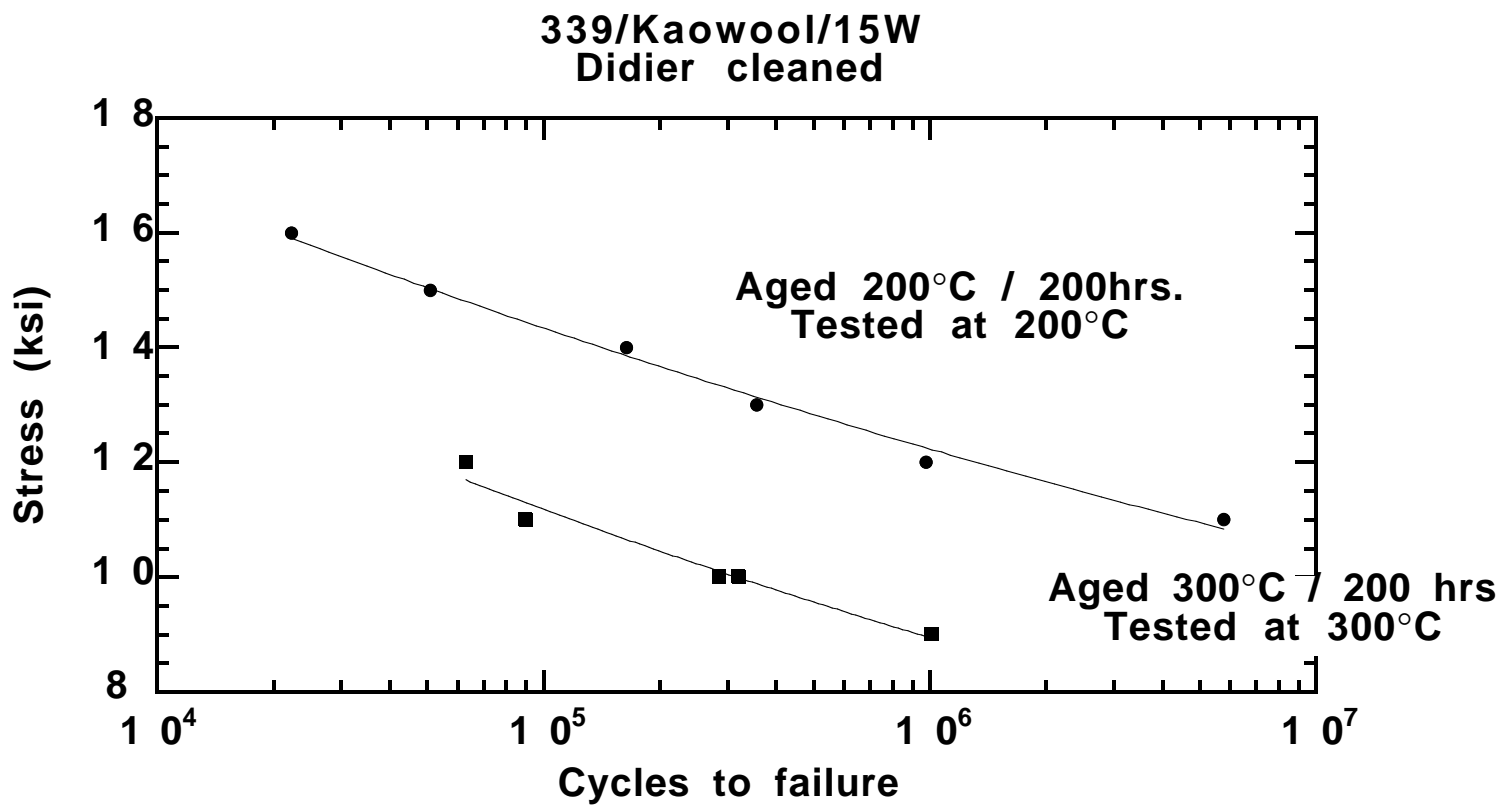

Fig. 6. Stress versus life for the Didier-cleaned 339/Kaowool/15w composite tested at $200^{\circ} \mathrm{C}$ and $300^{\circ} \mathrm{C}$. Samples were pre-annealed at the testing temperature for 200 hours before the fatigue experiments.

All fractures occurred perpendicular to the loading axis. For the high shot and low shot material, the defects initiating failure were almost always shot particles (through fracture of the particle) or porosity. For the Didier-cleaned material, on the other hand, failures were initiated at large pieces of reinforcement or inclusions. In the case of the large reinforcement, both fracture of the reinforcement as well as disbonds between the matrix and the reinforcement were observed. 
In Figs. 7 and 8 , the $\sigma-\mathrm{N}$ data obtained at $200^{\circ} \mathrm{C}$ and $300^{\circ} \mathrm{C}$ respectively are compared for the three types of metal matrix composites (MMCs). At both temperatures, the high shot material had a shorter fatigue life for a given cycling stress than either the low shot or Didier-cleaned material. The low shot and Didier-cleaned materials had very similar lives for a given cycling stress. The difference between the high shot MMC and the low shot / Didier-cleaned MMCs decreases with increasing life until at $10^{7}$ cycles to failure there is very little difference between the fatigue response of all three materials.

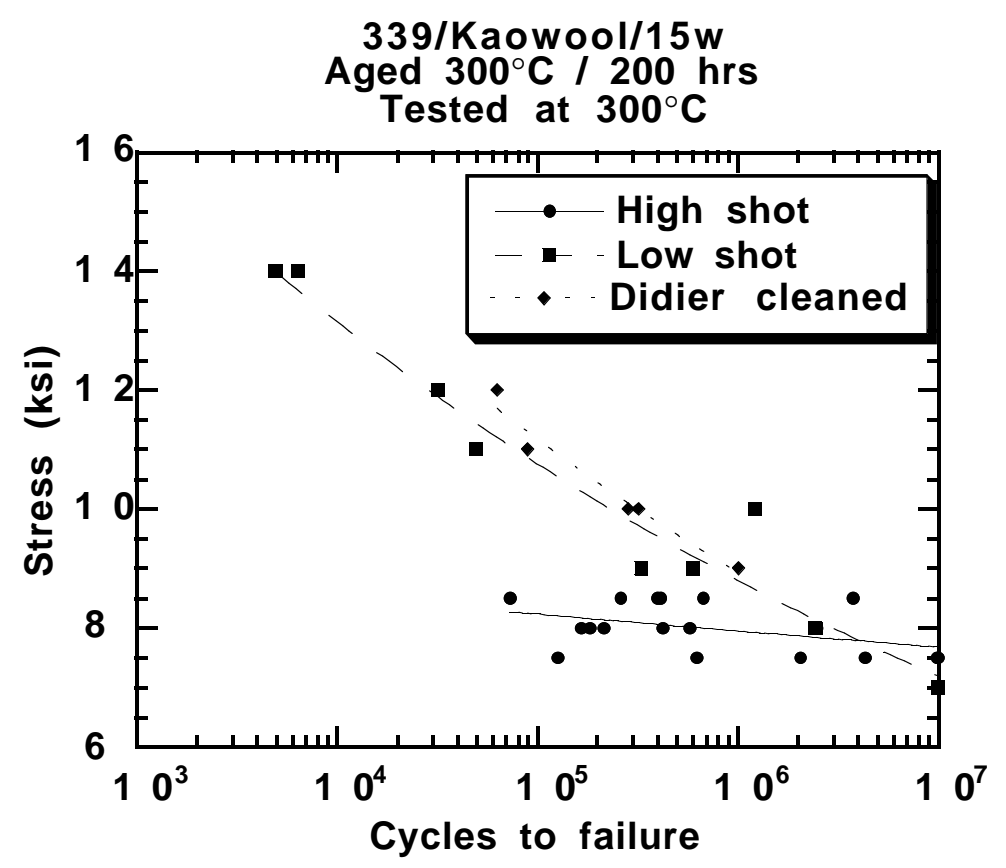

$339 /$ Kaowool/15W

All samples aged at $200^{\circ} \mathrm{C} / 200 \mathrm{hrs}$

Tested at $200^{\circ} \mathrm{C}$

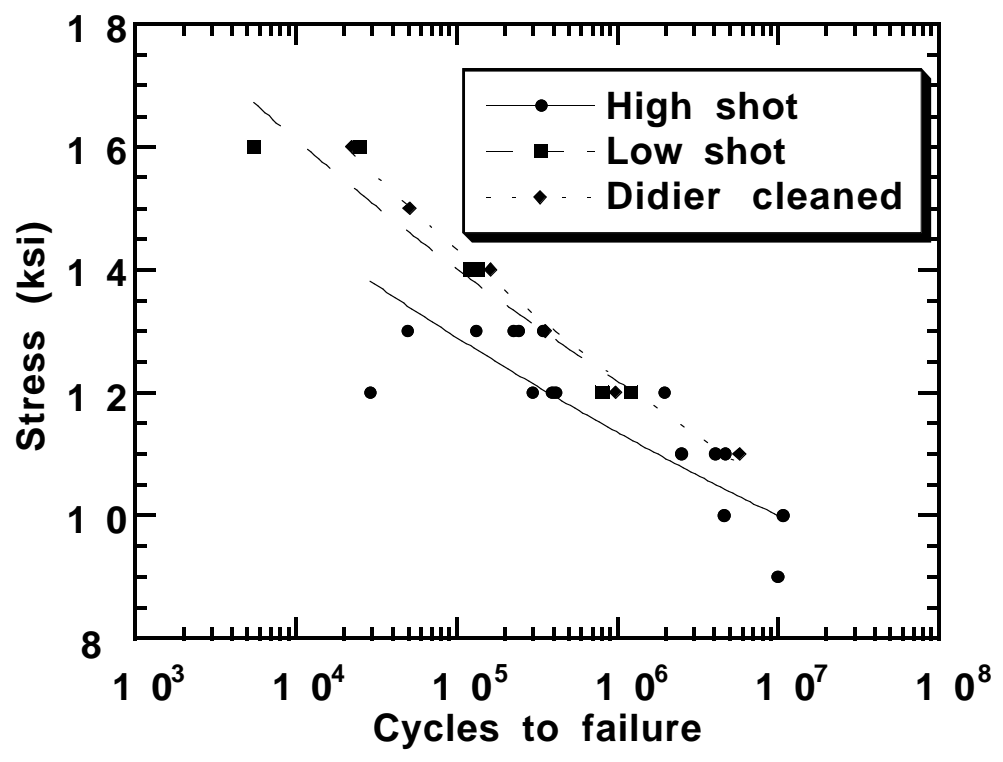

Fig. 7. Stress versus life for high shot, low shot and Didier-cleaned MMC at $300^{\circ} \mathrm{C}$.
Fig. 8. Stress versus life for high shot, low shot and Didier-cleaned MMC at $200^{\circ} \mathrm{C}$. 
The data shown in Fig. 4 is replotted in Fig. 9 as log stress versus log cycles to failure. As noted above, the relationship between cycling stress and life can be represented well by a power-law equation in the high cycle fatigue regime. Figure 9 also shows the extrapolation of the power law equation representing the $300^{\circ} \mathrm{C}$ data to the low cycle fatigue regime. The equation predicts an ultimate tensile strength (stress at $10^{\circ}$ cycles) of about $9.5 \mathrm{ksi}$. This strength is significantly less than the UTS measured in a monotonic tensile test of the 339/Kaowool/15w composite that had been aged for 200 hours at $300^{\circ} \mathrm{C}$ (approximately $20 \mathrm{ksi}$ [2]). The reason for this strength difference is that the tensile and fatigue tests have different failure origins. Failures in the fatigue tests generally initiated from well-defined defects whereas failures in the tensile tests generally could not be associated with a specific defect. This behavior is distinctly different from that observed by Nieh, Lesuer and Syn on the DWA 6090/SiC/25p MMC [3] at room temperature. In the $6090 / \mathrm{SiC} / 25 \mathrm{p}$ material, a power-law equation (derived from data in the range of $10^{3}$ to $10^{7}$ cycles to failure) extrapolated to the correct UTS. The origins of faitigue failure, however, are significantly different in the two materials. In $6090 / \mathrm{SiC} / 25 \mathrm{p}$, failures initiated within the matrix, whereas, in 339/Kaowool/15w, failures initiated at defects. It is important to recognize that, in the region of interest (high cycle fatigue), the data can be represented by a power-law equation.

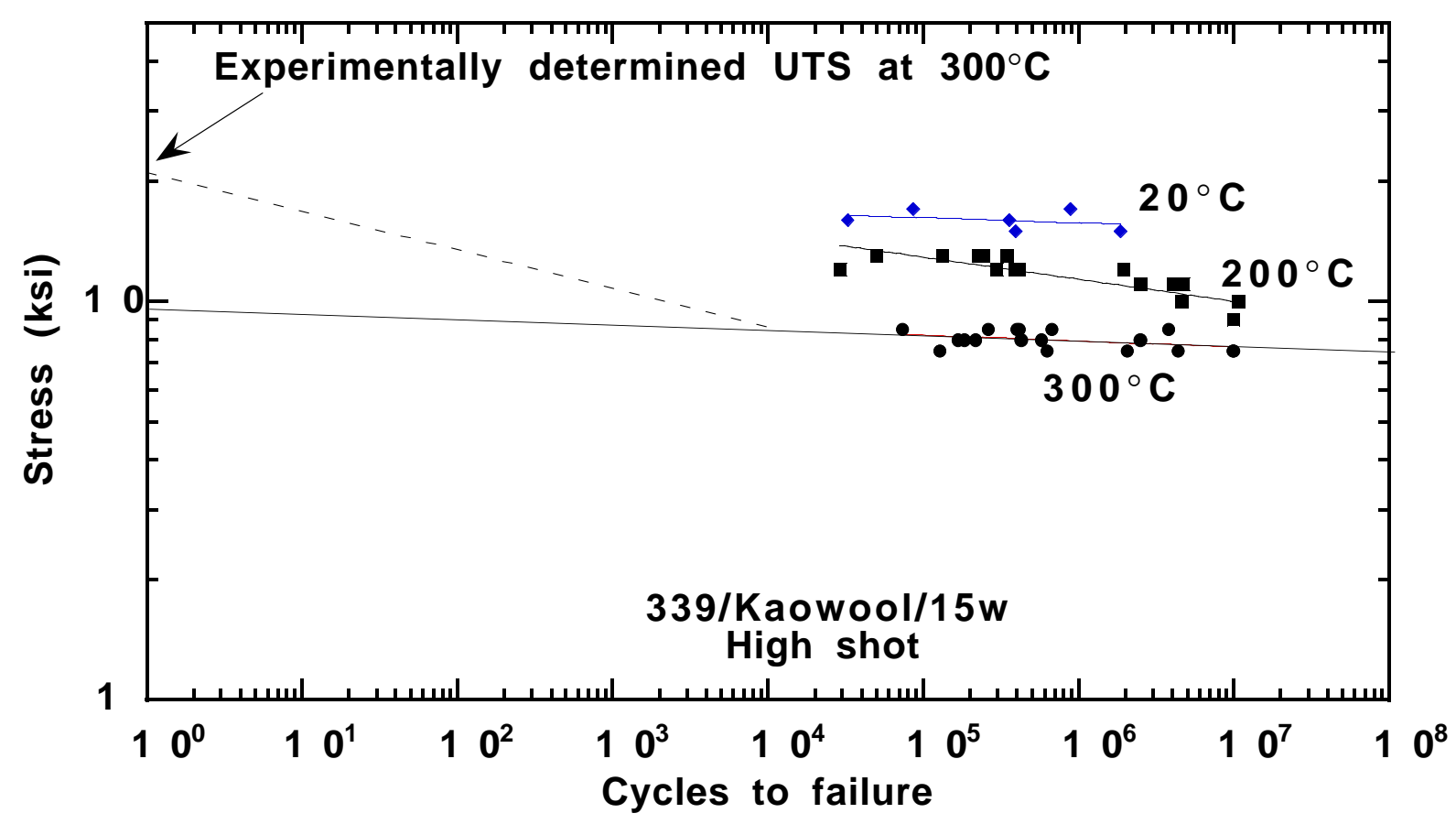

Fig. 9. Stress versus life (plotted on log-log axes) for the high shot $339 /$ Kaowool $/ 15 \mathrm{w}$ composite at $20^{\circ} \mathrm{C}, 200^{\circ} \mathrm{C}$ and $300^{\circ} \mathrm{C}$. 


\section{Influence of defect type and size .}

Background. A number of models have been proposed to describe the influence of defects and stress concentrations on fatigue strength. These models have been recently reviewed by Murakami and Endo [4] and can be loosely classified into three types - (1) models that are based on empirical equations, (2) models that are based on a notch (or stress concentration) factor, and (3) models that are based on fracture mechanics. A fracture mechanics-based model by Murakami and Endo [5] has been used as a reasonable starting point for analysis of the fatigue data reported here. The model relates the fatigue strength to the size of a defect responsible for failure. The model predicts a phenomenological equation of the form

$$
\sigma \mathrm{A}^{1 / \mathrm{n}}=\mathrm{C}
$$

where $\sigma$ is the fatigue strength (taken by Murakami and Endo to be the stress at $10^{7}$ cycles), $A$ is the cross-sectional area of the defect normal to the tensile axis, and $n$ and $\mathrm{C}$ are constants. The constant $\mathrm{n}$ will be referred to as the area exponent. The correlation between fatigue strength and defect size predicted by Equation (1) was evaluated by Murakami and Endo for a $.13 \% \mathrm{C}$ steel and a $.46 \% \mathrm{C}$ steel. Fatigue strengths were determined in a rotating bending test and a torsion test for samples that had small holes drilled into their surfaces. Excellent agreement was obtained between the predictions of Equation (1) and the experimental data.

As mentioned above, the Murakami and Endo model is based on fracture mechanics specifically, the influence of the shape and size of an elliptical crack on the stress intensity. The theoretical variation of this maximum stress intensity with area of the defect raised to the $1 / 4$ power is shown in Fig. 10. The maximum stress intensity and the area of the ellipse have been normalized by the stress intensity and area of a circle of unit radius. The dashed lines in the figure show that, for a given aspect ratio, the maximum stress intensity increases as the area of the elliptical crack to the 1/4 power. The results in Fig. 10 have been replotted in Fig. 11 to show more clearly the variation of the maximum stress intensity with defect aspect ratio. This figure will be referred to in the next section. The stress intensity factor shown in Fig. 10 can be assumed to characterize the local stress and strain field in the vicinity of the defect and thus the magnitude of the stress intensity can be related to the local stresses responsible for fatigue crack initiation and growth. Thus, in theory, the $n$ in Equation (1) should be equal to 4 . 

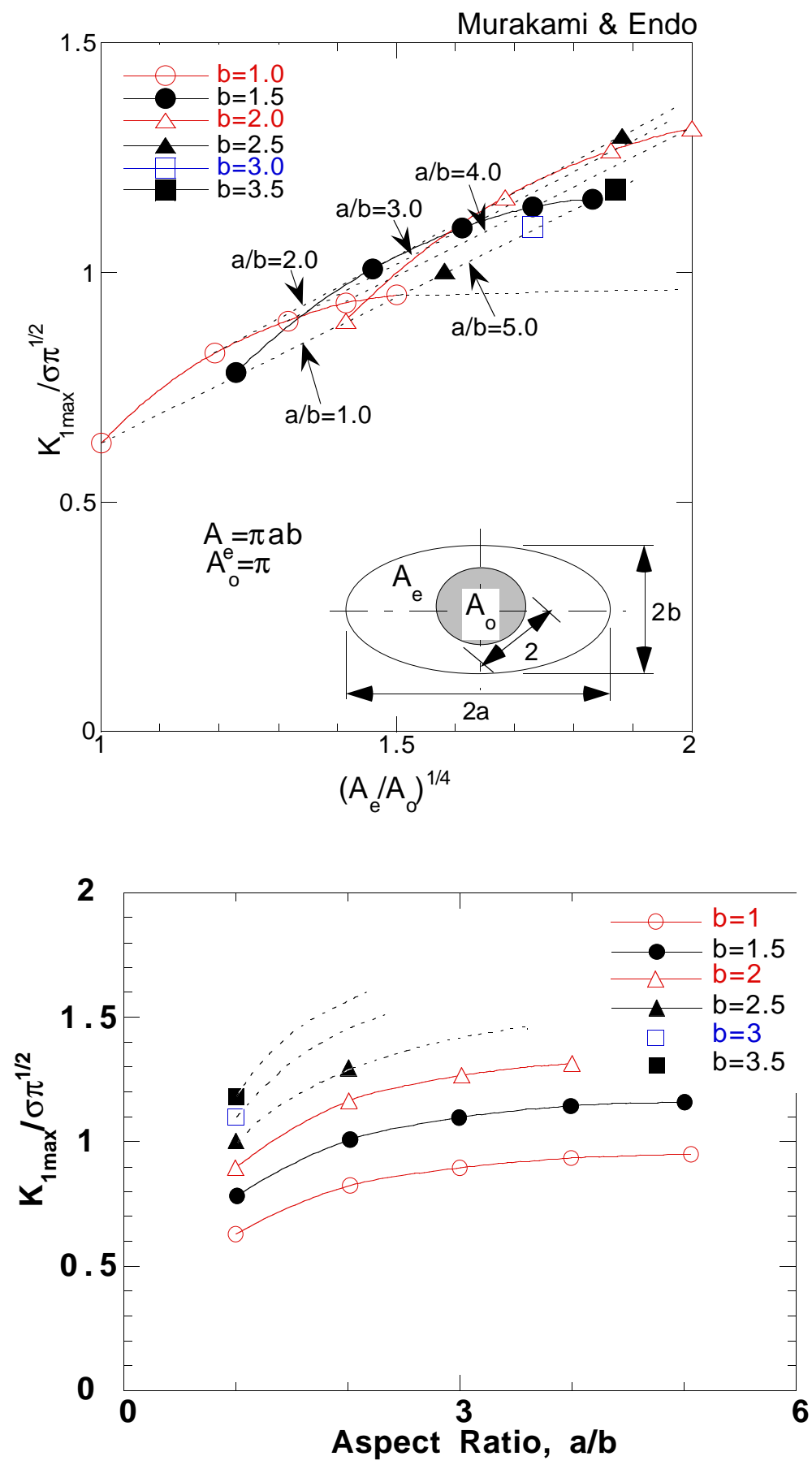

Fig. 10. Normalized maximum stress intensity for an elliptical defect (crack) versus the normalized cross-sectional area of the defect. Maximum stress intensity and the area of the defect have been normalized by the stress intensity and area of a circle of unit radius. Stress intensities are provided for five different crack aspect (a/b) ratios. (after Murakami and Endo [5]).
Fig. 11. Normalized maximum stress intensity for an elliptical defect (crack) versus aspect ratio. Data is replotted from Fig. 10.

As discussed in a previous section, there are significant differences in the failure origins observed in the high shot and low shot materials relative to the Didier-cleaned material. We have focused on the data sets resulting from the high shot and low shot materials and have applied Equation (1) to these data. Sufficient data were available for failures originating from shot particles and porosity at $200^{\circ} \mathrm{C}$ and shot particles at $300^{\circ} \mathrm{C}$ to make a valid assessment of Equation (1). We have evaluated Equation (1) for a fatigue strength defined at $10^{7}$ cycles as well as $10^{5}$ cycles. 
Shot particles $-200^{\circ} \mathrm{C}$. Fatigue data are plotted in Fig. 12 for $339 / \mathrm{Kaowool} / 15 \mathrm{w}$ samples tested at $200^{\circ} \mathrm{C}$ that had failures initiating at shot particles. It is important to recognize that all the 339/Kaowool/15w data in the Appendix for low and high shot material with shot particle-initiated failures at $200^{\circ} \mathrm{C}$ are shown in the figure.

The local stress intensity and $\sigma-\mathrm{N}$ response of the 339/Kaowool composites are influenced by the characteristics of the defect structure. For shot particles (as well as porosity), the most significant characteristics are defect shape, location and size. These characteristics are noted for each data point in Fig. 12 as the dimensions of the shot particle (in $\mu \mathrm{m}$ ), its location below the surface (in $\mu \mathrm{m}$ ), and the cross-sectional area (in $\mu \mathrm{m}^{2}$ ). The cross sectional area (A) was calculated from the dimensions, assuming an ellipse, using the formula

$$
A=\pi a b,
$$

where $a$ and $b$ are $1 / 2$ the major and minor axes, respectively, as shown for the ellipse provided in the inset drawing of Fig. 10. Examination of the defect data in Fig. 12 shows that the location and aspect ratio of the shot particles are not significant variables in the fatigue data. This conclusion is based on the following three observations. (a) All shot particles were located at or near the surface. (All "near surface" particles were located significantly less than the radius of the particle from the surface.) (b) The aspect ratio (b/a in Fig. 10) varies from 1 to 2.5 , which can introduce an uncertainty in $\mathrm{K}_{\max }$ of about $30 \%$, as shown in Fig. 11. (c) The defect area varies by over a factor of two, which can produce a change in $\mathrm{K}_{\max }$ of over a factor of two. Thus the most significant variable that influences the $\sigma-\mathrm{N}$ behavior in this study is defect size, and the data in Fig. 12 will be analyzed relative to this variable.

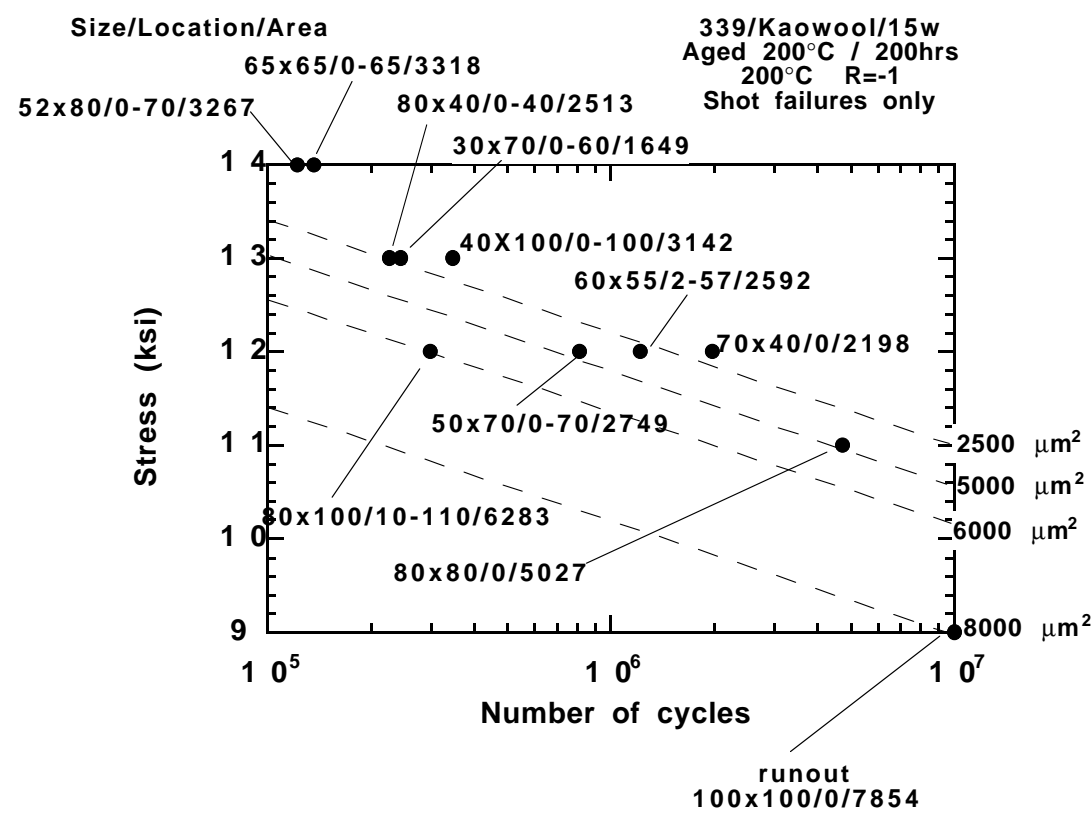

Fig. 12. Stress versus number of cycles for 339/Kaowool/15w samples with failures originating from shot particles. Samples were tested at $200^{\circ} \mathrm{C}$. The size, location and area of the shot particles initiating failure are indicated. Curves have been constructed to show the $\sigma-N$ response expected for defects of a given cross-sectional area. 
Based on the data points given in Fig. 12, $\sigma-\mathrm{N}$ curves were constructed for defects of constant size. These curves were constructed for defect areas equal to $2500 \mu^{2}, 5000$ $\mu \mathrm{m}^{2}, 6000 \mu \mathrm{m}^{2}$ and $8000 \mu \mathrm{m}^{2}$. The fatigue strengths at $10^{5}$ and $10^{7}$ cycles to failure were then plotted as a function of defect area. The results are given in Fig. 13 and show that the fatigue strength at both $10^{5}$ and $10^{7}$ cycles can be represented as a power law function of the defect area as predicted by Equation (1). The area exponent ( $n$ ) from Equation (1) for the $200^{\circ} \mathrm{C}$ shot particle failures is given in Table I and compared with $\mathrm{n}$ exponents from other studies. In all cases, the $\mathrm{n}$ value is larger than the theoretical value of 4 . Thus the local stress intensity is not as high as the theoretical prediction. Murakami and Endo observed this deviation from theory and attributed it to crack length effects and the difference between "small and large-scale yielding". For all the defects shown in Table I, the defect sizes are small enough that the material can no longer be treated as a continuum (as assumed in the analysis of Fig. 10) and short crack effects must be considered.

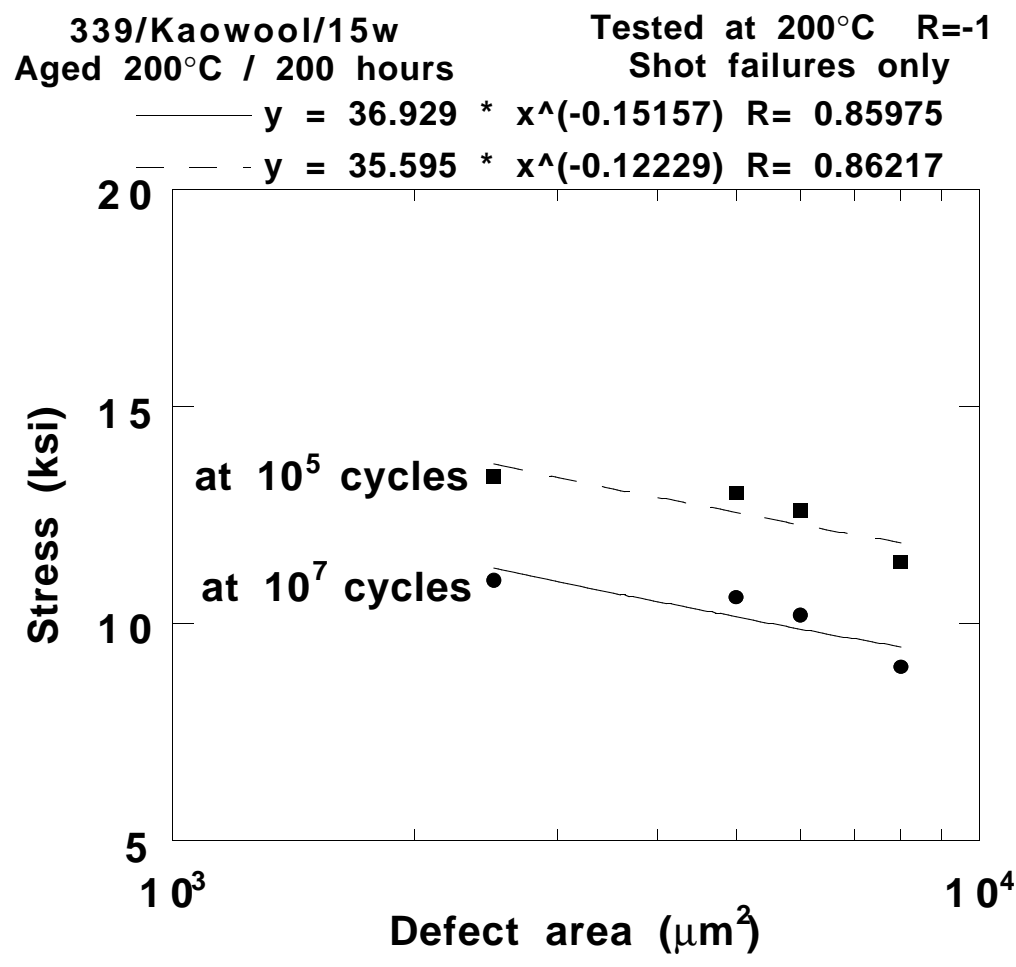

Fig. 13. Fatigue strength at $10^{5}$ and $10^{7}$ cycles versus defect area for 339/Kaowool/15w with failures due to shot particles at $200^{\circ} \mathrm{C}$. Lines represent a power law fit to the data. 
Table I

Area Exponent (n) from Equation (1)

\begin{tabular}{|c|c|c|c|c|c|c|}
\hline Material & Defect type & $\begin{array}{c}\text { Range in } \\
\text { defect size } \\
(\mu \mathrm{m})^{1}\end{array}$ & $\begin{array}{c}\text { Testing } \\
\text { temperature } \\
\left({ }^{\circ} \mathrm{C}\right)\end{array}$ & $\begin{array}{l}\text { Testing } \\
\text { method }\end{array}$ & $\mathrm{n}$ & Reference \\
\hline $.46 \%$ C steel & drilled holes & $40-500$ & 20 & bending & 12.0 & 5 \\
\hline $.13 \% \mathrm{C}$ steel & drilled holes & $40-500$ & 20 & bending & 11.2 & 5 \\
\hline $.46 \% \mathrm{C}$ steel & drilled holes & $40-500$ & 20 & torsional & 13.4 & 5 \\
\hline $.39 \%$ C steel & irregular drilled holes & & 20 & bending & 4.6 & 56 \\
\hline $.39 \%$ C steel & irregular drilled hole & & 20 & torsional & 7.2 & 56 \\
\hline $.46 \% \mathrm{C}$ steel & unknown & & unknown & $\begin{array}{l}\text { rotating } \\
\text { bending }\end{array}$ & 5.2 & 5,7 \\
\hline $.46 \%$ c steel & unknown & & unknown & $\begin{array}{l}\text { rotating } \\
\text { bending }\end{array}$ & 8.0 & 5,7 \\
\hline 339/Kaowool/15w & shot particles & $40-100$ & 200 & axial & 6.6 & $\begin{array}{l}\text { present study } \\
\text { (Fig. 13) }\end{array}$ \\
\hline 339/Kaowool/15w & shot particles & $40-100$ & 200 & axial & 13.0 & $\begin{array}{l}\text { present study } \\
\text { (Fig. 16) }\end{array}$ \\
\hline 339/Kaowool/15w & porosity & $50-350$ & 200 & axial & 13.8 & $\begin{array}{l}\text { present study } \\
\text { (Fig. 20) }\end{array}$ \\
\hline 339/Kaowool/15w & porosity & $50-350$ & 200 & axial & 24.3 & $\begin{array}{c}\text { present study } \\
\text { (Fig. 23) }\end{array}$ \\
\hline 339/Kaowool/15w & shot particles & $20-160$ & 300 & axial & 9.0 & present study \\
\hline 2124/SiC/20p-T6 & SiC particles & $3-35$ & 20 & axial & 11.8 & $\begin{array}{l}\text { present study } \\
\text { (data from } \\
\text { ref. 9) }\end{array}$ \\
\hline
\end{tabular}

The model presented by Murakami and Endo relates fatigue strength to defect size. The area exponent $(n)$ and constant $(C)$ in Equation (1) characterize the local stress intensity resulting from shot particles at $200^{\circ} \mathrm{C}$. This characterization of the stress intensity can be used in a new model that can predict the life of samples as a function of stress and defect characteristics (size and type). The model is based on the wellestablished empirical equation [8] relating the maximum stress $(\sigma=\Delta \sigma / 2)$ and life $(\mathrm{N})$, namely,

$$
\mathrm{N}=\mathrm{C}_{1} \sigma^{\mathrm{p}}
$$

where $C_{1}$ and $p$ are experimentally determined constants. The model assumes that a similar power-law equation relates $\mathrm{N}$ and $\mathrm{K}_{\max }$ (also referred to as $\mathrm{K}$ ). Thus

$$
\mathrm{N}=\mathrm{C}_{2} \mathrm{~K}^{\mathrm{q}}
$$

where $q$ and $C_{2}$ are constants. Since $K$ varies as $\sigma A^{1 / n}$ in Equation (1), Equation (4) can be written as

$$
N=C_{3}\left(\sigma A^{1 / n}\right)^{q}
$$

\footnotetext{
1 taken as the minimum and maximum dimensions observed in the data.
} 
where $\mathrm{C}_{3}$ is again a constant. The data in Fig. 12 has been analyzed using Equation (5) and the value of $n$ determined in Fig. 13. Results are shown in Fig. 14, in which the life is plotted against the local stress intensity for shot particles tested at $200^{\circ} \mathrm{C}$. The plot shows that the fatigue data, which includes cycling stress as well as defect area, can be represented well by Equation (5).

The life equation for shot failures at $200^{\circ} \mathrm{C}$ in the $339 / \mathrm{Kaowool} / 15 \mathrm{w}$ composite is given by

$$
N=3.8310^{26}\left(\sigma A^{.15}\right)^{-12.9}
$$

The life calculated from this equation, assuming a range of cycling stresses and defect areas observed in this study, is compared in Fig. 15 with the life obtained experimentally. As can be seen, the agreement is excellent; the equation can predict life to better than half a decade. It should be mentioned that all the data in the Appendix for shot failures at $200^{\circ} \mathrm{C}$ (including low shot and high shot, pre-aged material - 12 data points) are given in the figure.

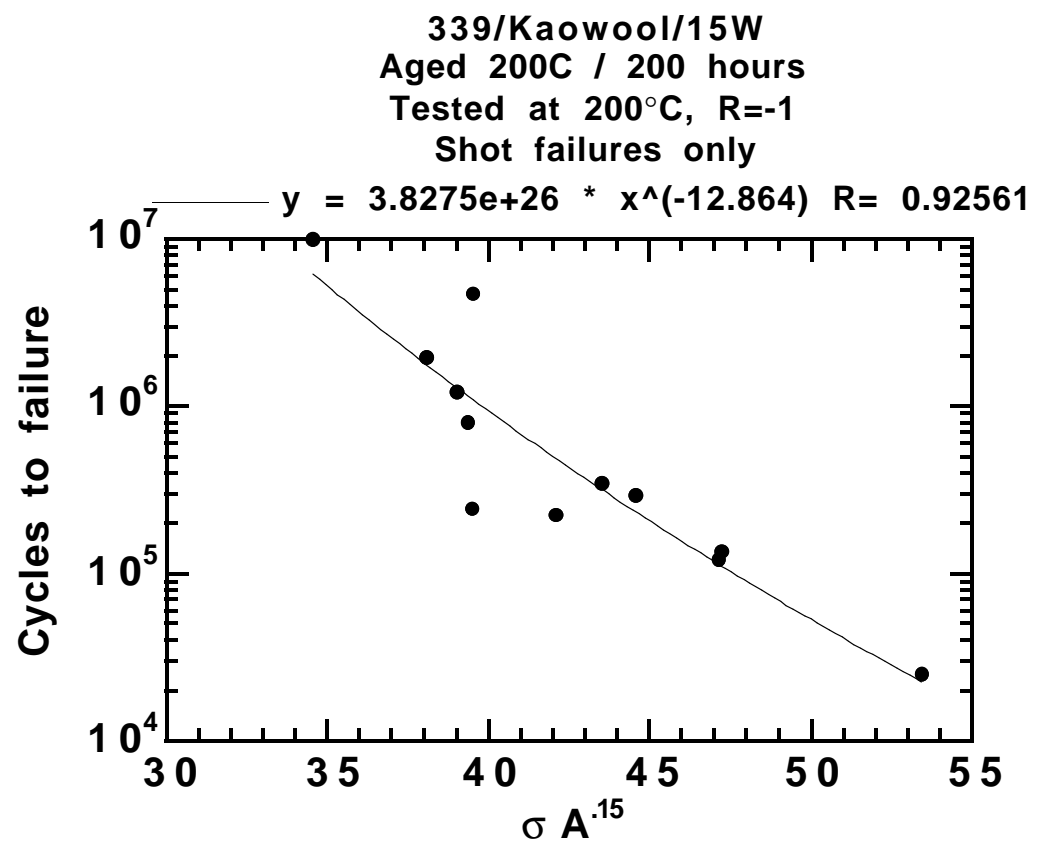

Fig. 14. Cycles to failure versus local stress intensity for shot failures at $200^{\circ} \mathrm{C}$. Local stress intensity $(\sigma A .15)$ is derived from the analysis in Fig. 13. Line represents a power law fit to the data. 


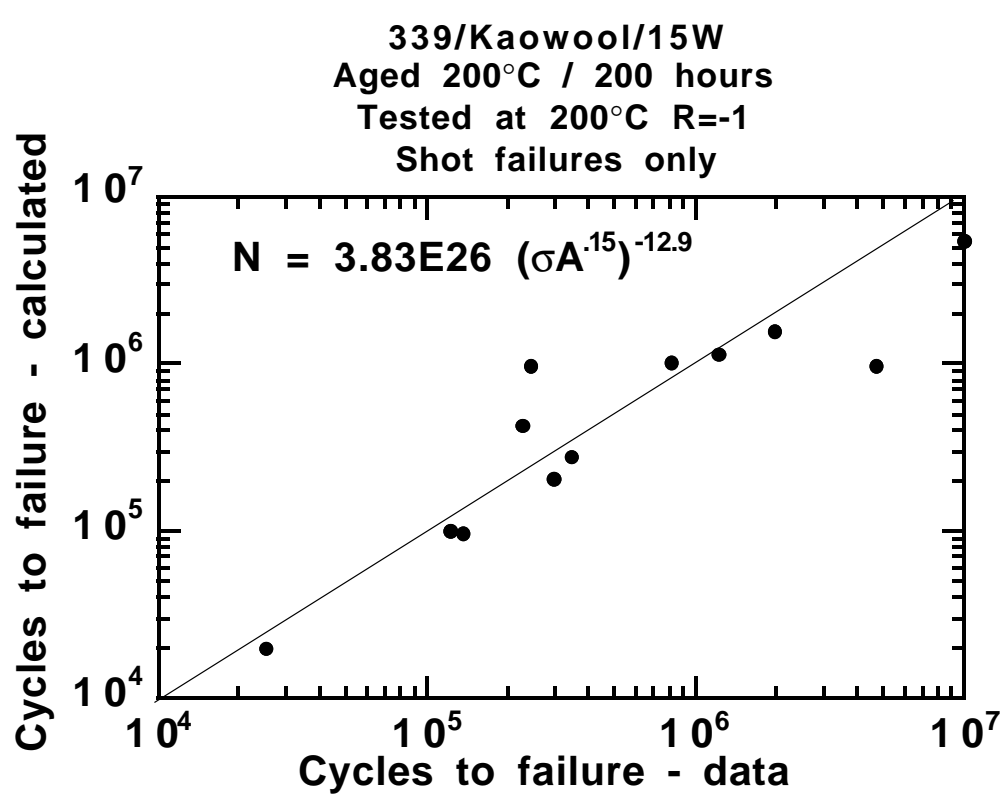

Fig. 15. Calculated number of cycles to failure versus experimental data. Calculations are based on the equation shown in the figure.

Further analysis of the data in Fig. 13 suggests that there may be breaks in the stress defect area curves as shown in Fig. 16. Each curve has two segments with different area exponents. A change in area exponent with decreasing defect area might be expected, since at small defect sizes, short crack effects can be expected to be observed. As noted earlier, the $\mathrm{n}$ value is significantly larger than the theoretical value of 4 at these small defect sizes. It is interesting to note that the break in the curve results in an $n$ value at large defect sizes that approaches 4 (the value predicted by fracture mechanics). Thus the results in Fig. 16 suggest that at large defect sizes long crack effects are obtained and the material can be treated as a continuum with $n$ approximately equal to 4 . At small defect sizes, short crack effects are observed and the $\mathrm{n}$ values are significantly larger than 4 .

$339 /$ Kaowool/15w Aged $200^{\circ} \mathrm{C} / 200$ hours
Tested at $200^{\circ} \mathrm{C} R=-1$ Shot failures only

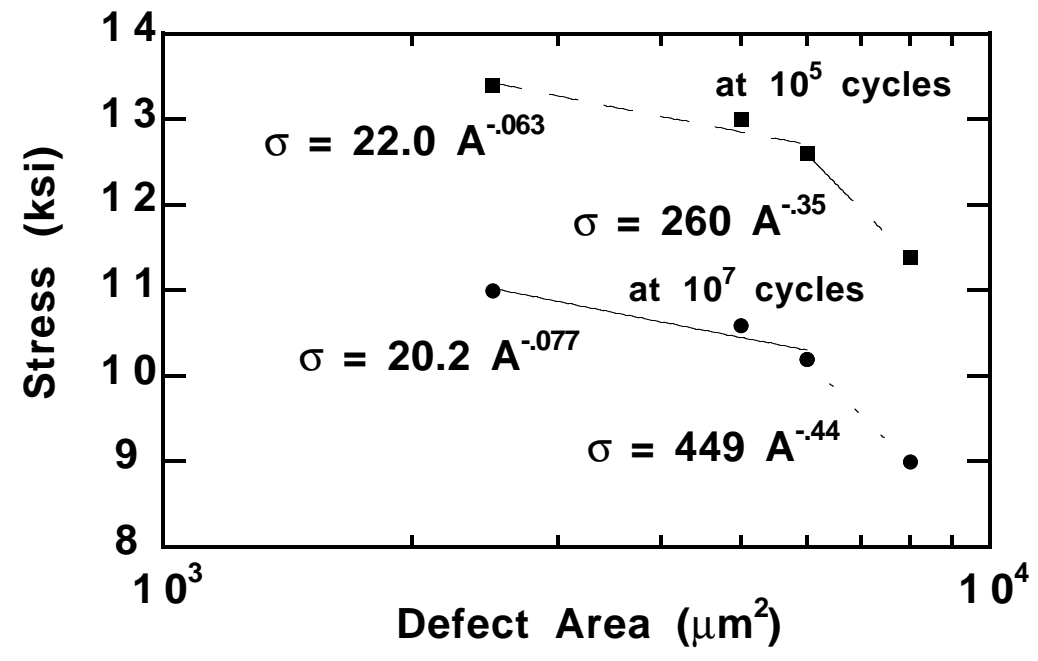

Fig. 16. Analysis of the data in Fig. 13 showing a break in the curve at defect size equal to $6,000 \mu \mathrm{m}^{2}$. 
We have analyzed all the data in Fig. 14 as previously described using Equation (5). The area exponent at small defect sizes was used in the analysis, since most of the data (with the exception of 2 data points) had defect sizes less than $6000 \mu \mathrm{m}^{2}$. The results are shown in Figs. 17 and 18. The life equation obtained from this analysis was

$$
N=1.1710^{23}\left(\sigma A^{.077}\right)^{-12.7}
$$

Agreement between calculated life and experimental data is excellent with the equation predicting life to better than half a decade.
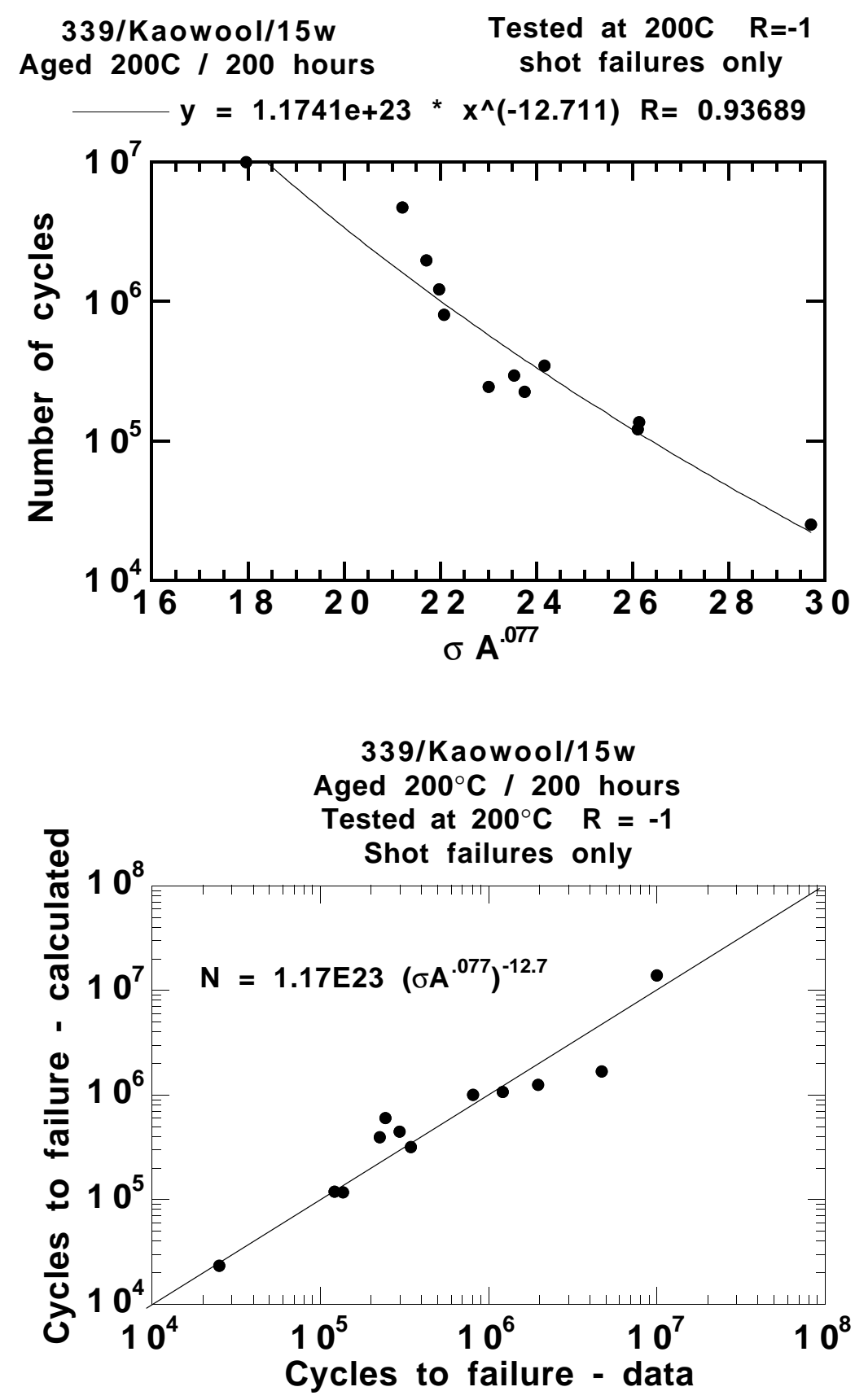

Fig. 17. Cycles to failure versus local stress intensity for shot failures at $200^{\circ} \mathrm{C}$. Local stress intensity $\left(\sigma A^{.077}\right)$ is derived from the analysis at small defect sizes (less than 6,000 $\mu m^{2}$ ) in Fig. 16. Line represents a power law fit to the data.
Fig. 18. Calculated number of cycles to failure versus experimental data. Calculations are based on the equation shown in the figure. 
Porosity $-200^{\circ} \mathrm{C}$. The fatigue data for porosity-initiated failures at $200^{\circ} \mathrm{C}$ was analyzed using the same methodology as the data above. The results are shown in Fig. 19 and $\sigma-\mathrm{N}$ curves for defects of constant size were constructed for porosity areas of $2500 \mu \mathrm{m}^{2}$, $10,000 \mu \mathrm{m}^{2}, 14,000 \mu \mathrm{m}^{2}$ and $28,000 \mu \mathrm{m}^{2}$. It is important to recognize that all the $339 / \mathrm{Kaowool} / 15 \mathrm{w}$ data in the Appendix with porosity-related failures at $200^{\circ} \mathrm{C}$ are shown in the figure. The fatigue strengths at $10^{5}$ and $10^{7}$ cycles are plotted versus defect area in Fig. 20 and reasonable agreement is obtained with Equation (1). The area exponent $(n)$, recorded in Table I, is 13.8 and is larger than the $n$ obtained from shot particles in the 339/Kaowool/15w composite or from the drilled holes in the data analyzed by Murakami and Endo. This result indicates that the local stress intensity resulting from porosity is a weaker function of defect area than the stress intensity resulting from other defects. This effect is caused by differences in the two types of defects. Porosity has ligaments spanning the defect region, whereas the shot and drilled holes do not. The ligaments present in the porosity defects are load bearing and reduce the local stress intensity experienced by the most highly stressed region of the defect. The result is that at large defect sizes, porosity is less damaging than shot for defects of the same cross-sectional area.

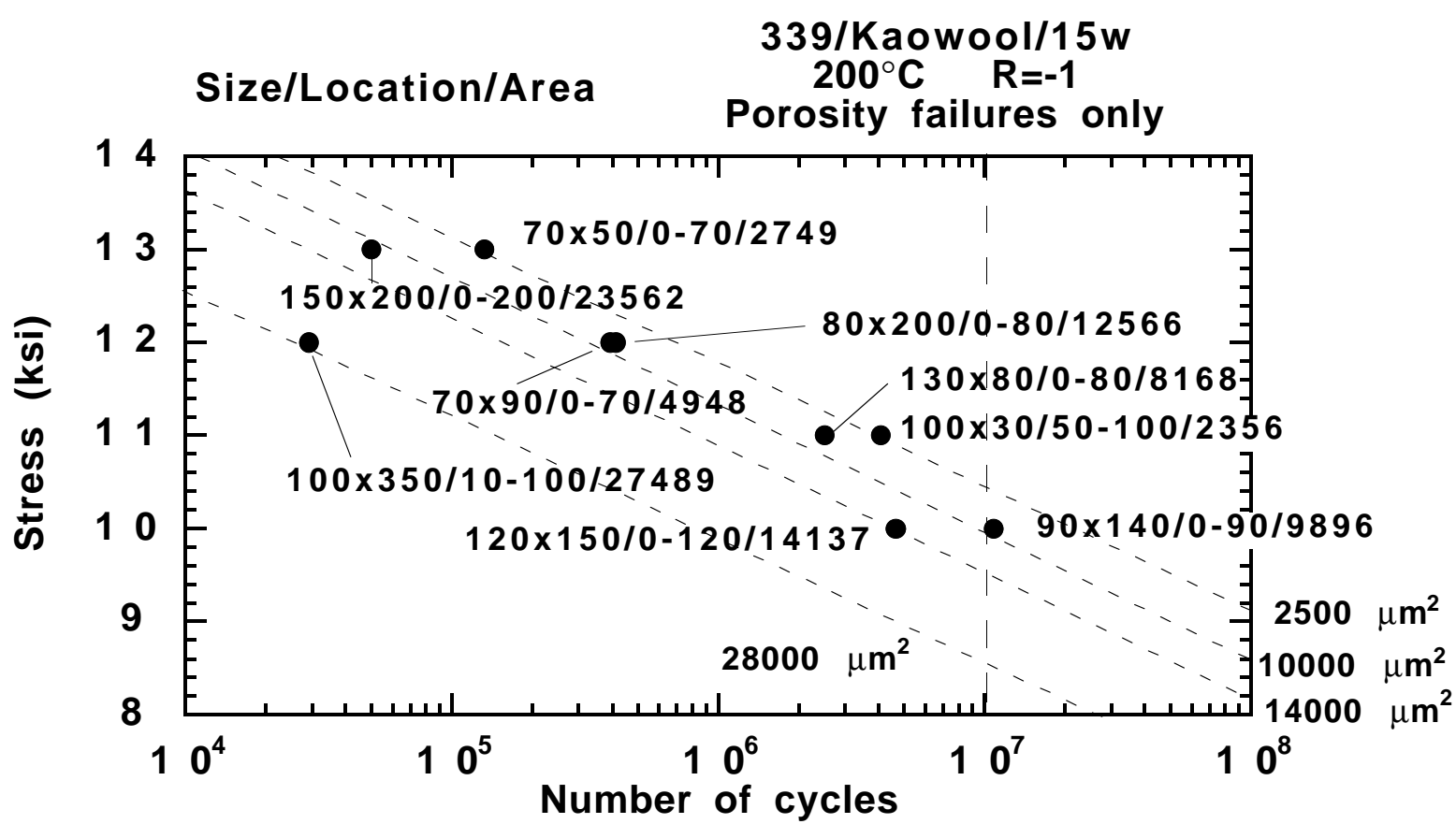

Fig. 19. Stress versus number of cycles for 339/Kaowool/15w samples with failures originating from porosity. Samples were tested at $200^{\circ} \mathrm{C}$. The size, location and area of the porosity regions initiating failure are indicated. Curves have been constructed to show the $\sigma-N$ curves expected for defects of a given cross-sectional area. 


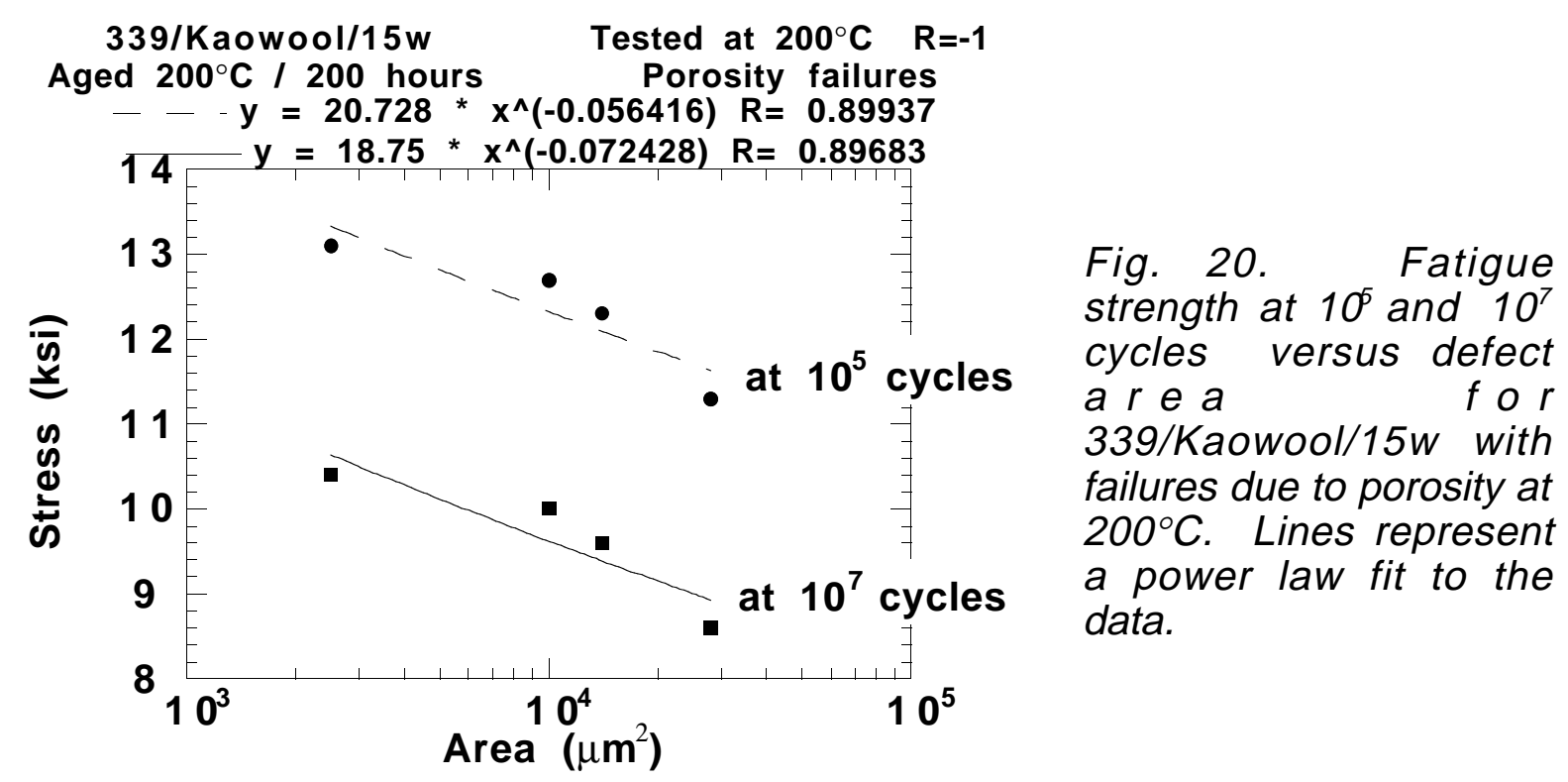

The porosity data at $200^{\circ} \mathrm{C}$ were evaluated according to Equation (5) using the area exponent recorded in Table I. The results are shown in Fig. 21 for the nine porosity failures observed in pre-aged samples at $200^{\circ} \mathrm{C}$. As with the shot failures at $200^{\circ} \mathrm{C}$, Equation (5) represents well the variation of life with the local stress intensity. This equation is

$$
\mathrm{N}=7.2710^{28}\left(\sigma \mathrm{A}^{.072}\right)^{-17.2}
$$

The life predicted by this equation is compared with experimental data in Fig. 22. With the exception of one data point, calculated values differ from experimental values by at most half a decade.

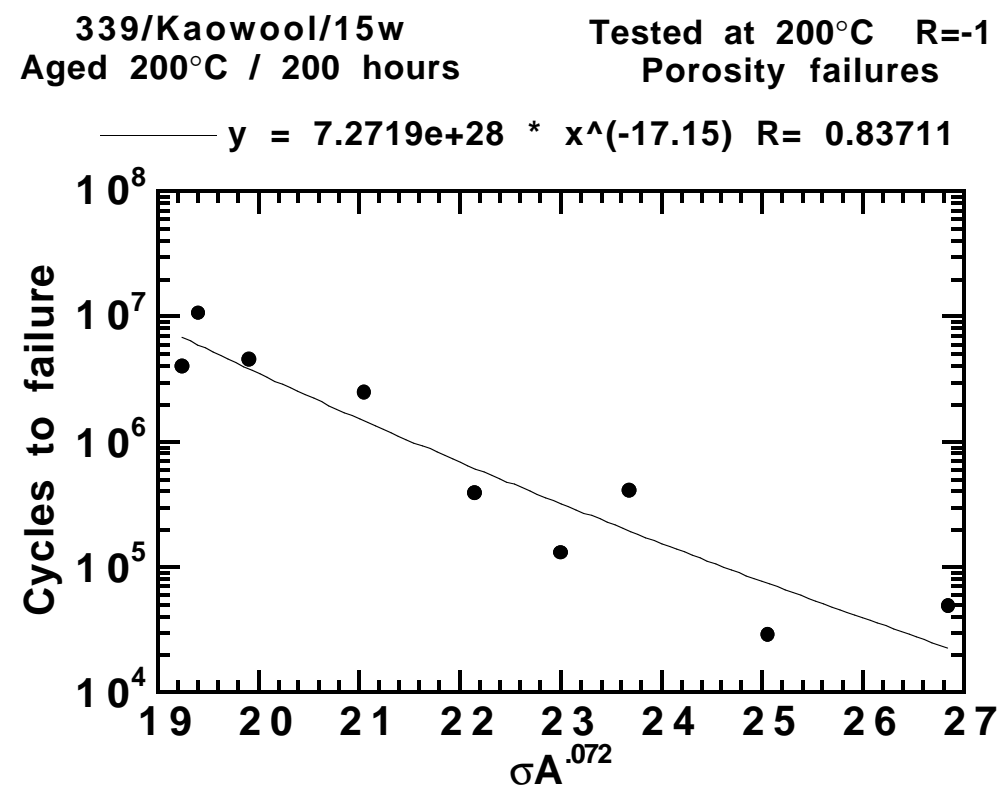

Fig. 21. Cycles to failure versus local stress intensity for porosity failures at $200^{\circ} \mathrm{C}$. Local stress intensity ( $\sigma A .072$ ) is derived from the analysis in Fig. 14 . Line represents a power law fit to the data. 


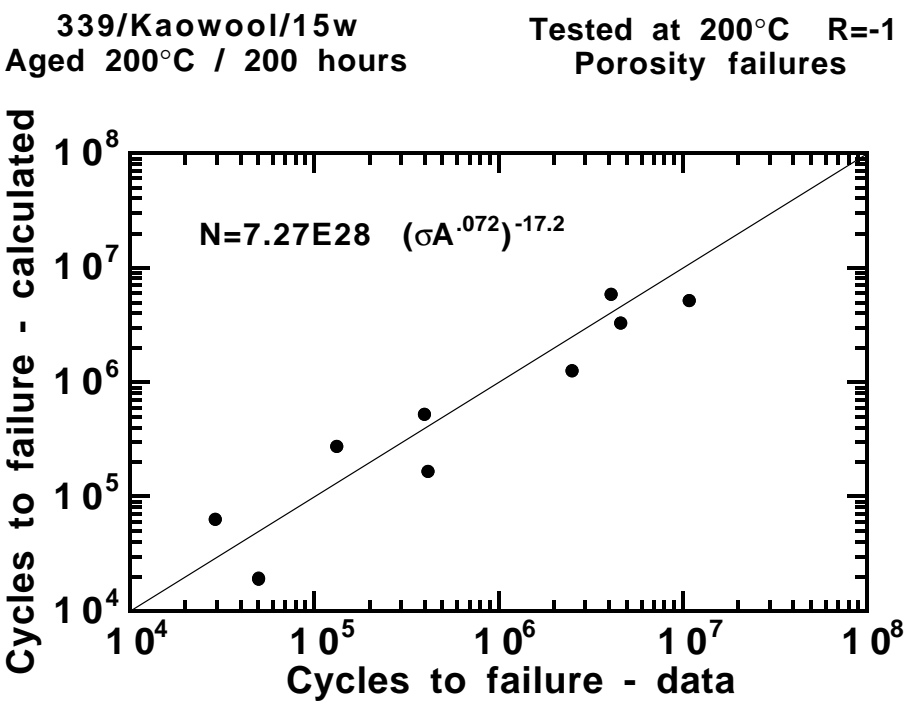

Fig. 22. Calculated number of cycles to failure versus experimental data. Calculations are based on the equation shown in the figure.

Further analysis of the data in Fig. 20 suggests that, as with the $200^{\circ} \mathrm{C}$ shot failure data, there may be a break in the stress - defect area curve as shown in Fig. 23. Thus the data for both $10^{5}$ cycles and $10^{7}$ cycles can be represented by two line segments (with two different area exponents) as shown in the figure. We have anaylyzed all the data in Fig. 14 as previously described using Equation (5). As with the $200^{\circ} \mathrm{C}$ shot failure data, we have used the area exponent for the curve segment at small defect sizes (less than $14,000 \mu \mathrm{m}^{2}$ ), since most of the data results from defects that are less than $14,000 \mu \mathrm{m}^{2}$. The results are shown in Figs. 24 and 25 . The life equation obtained from this analysis was

$$
\mathrm{N}=2.8510^{29}\left(\sigma \mathrm{A}^{.041}\right)^{-19.3}
$$

Agreement between calculated life and experimental data is excellent with the equation predicting life to better than half a decade.

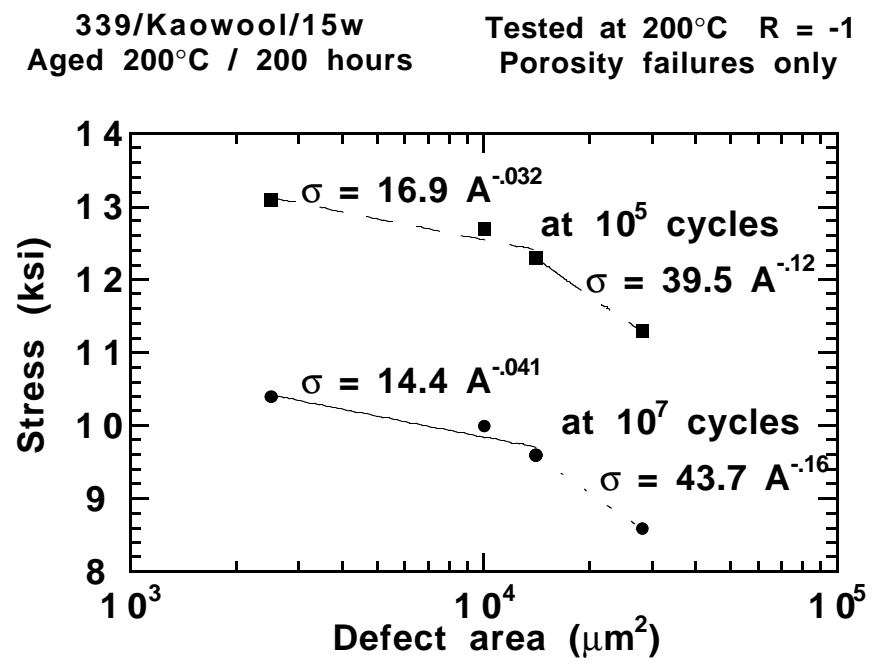

Fig. 23. Analysis of the data in Fig. 20 showing a break in the curve at defect size equal to $14,000 \mu \mathrm{m}^{2}$. 
$339 / \mathrm{KaOwool} / 15 \mathrm{w}$

Aged at $200^{\circ} \mathrm{C} / 200$ hours
Tested at $200^{\circ} \mathrm{C} \quad \mathrm{R}=-1$

Porosity failures

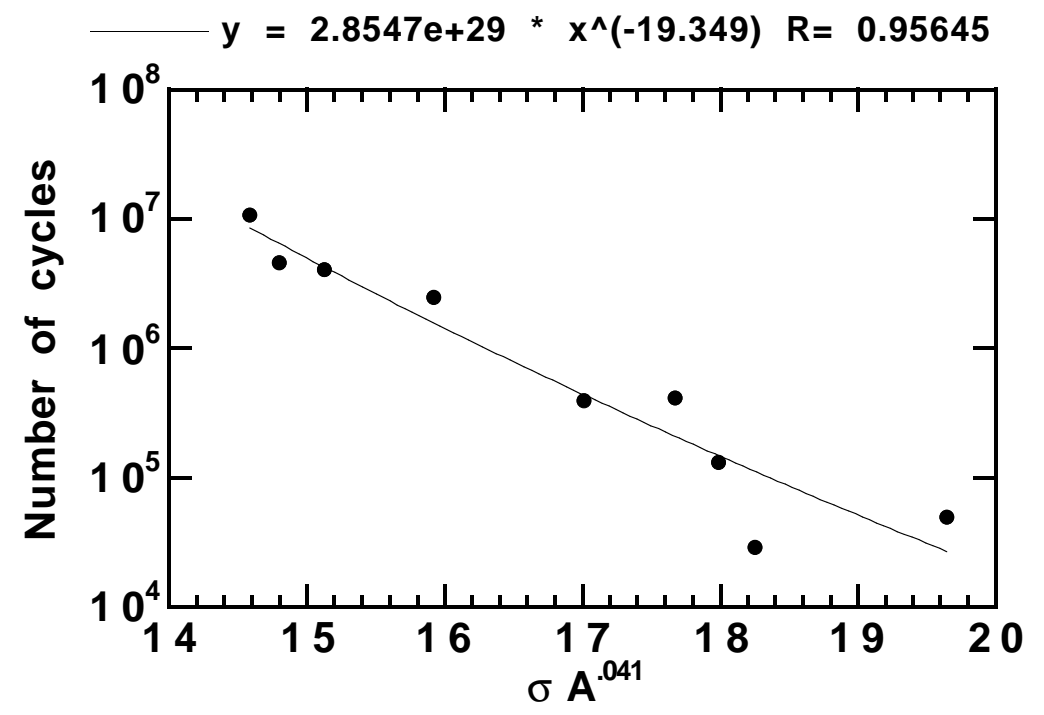

Fig. 24. Cycles to failure versus local stress intensity for porosity failures at $200^{\circ} \mathrm{C}$. Local stress intensity $\left(\sigma \mathrm{A}^{.041}\right)$ is derived from the analysis at small defect sizes (less than 14,000 $\mu \mathrm{m}^{2}$ ) in Fig. 23. Line represents a power law fit to the data.

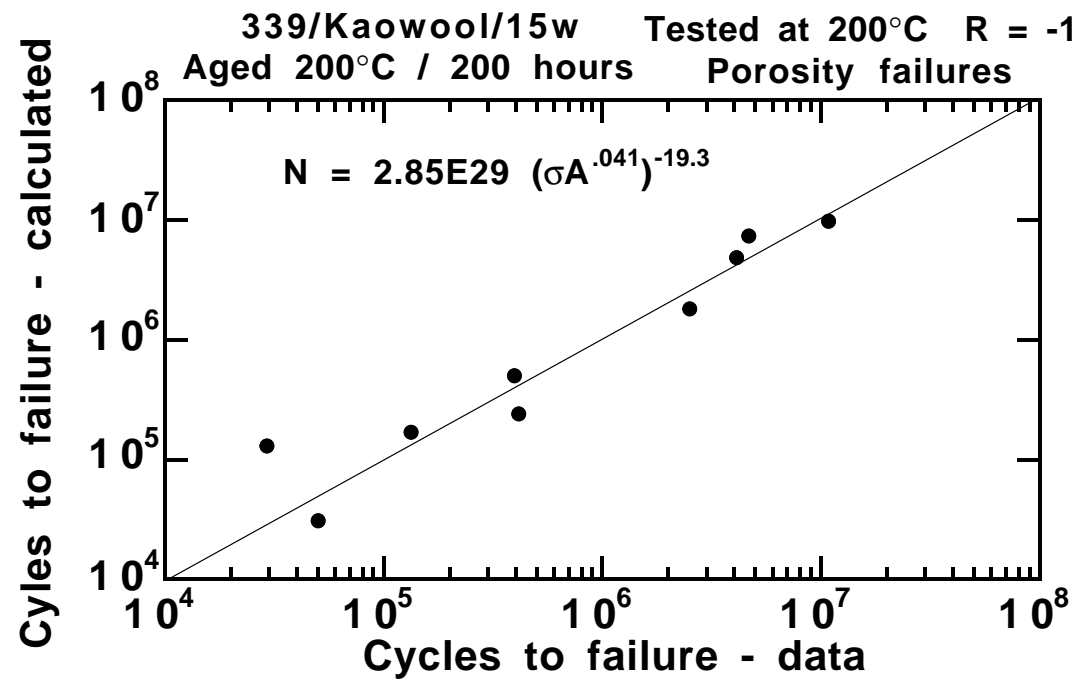

Fig. 25. Calculated number of cycles to failure versus experimental data. Calculations are based on the equation shown in the figure.

Shot particles $-300^{\circ} \mathrm{C}$. The fatigue data for shot-initiated failures at $300^{\circ} \mathrm{C}$ were analyzed using the same methodology as the $200^{\circ} \mathrm{C}$ data for shot and porosity failures. Ten samples were suitable for analysis and the results are reported in Figs. 26 - 29. The fatigue strengths at $10^{5}$ and $10^{7}$ cycles to failure are plotted against defect area in Fig. 27 and the results show reasonable agreement with Equation (1). 


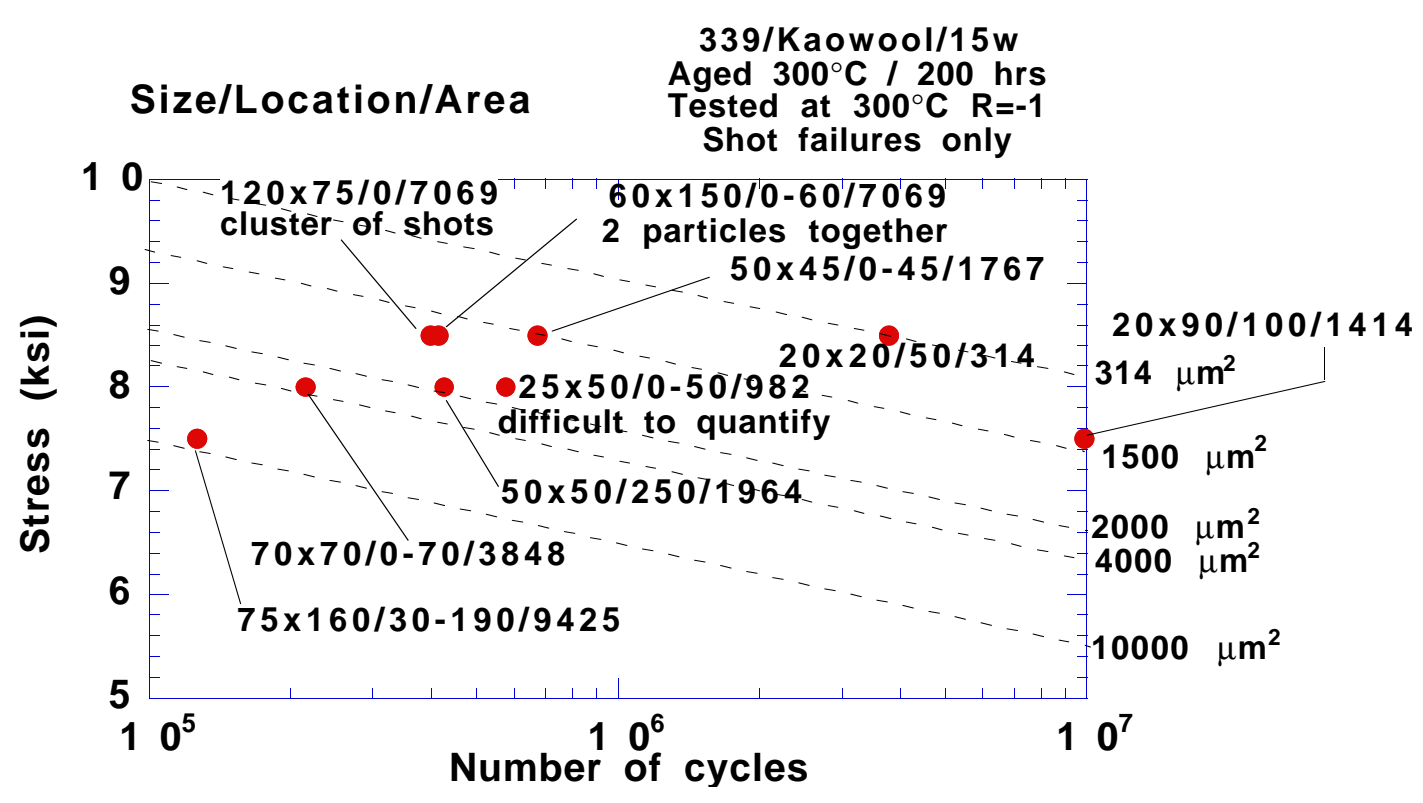

Fig. 26. Stress versus number of cycles for 339/Kaowool/15w samples with failures originating from shot particles. Samples were tested at $300^{\circ} \mathrm{C}$. The size, location and area of the shot particles initiating failure are indicated. Curves have been constructed to show the $\sigma-N$ curves expected for defects of a given cross-sectional area.

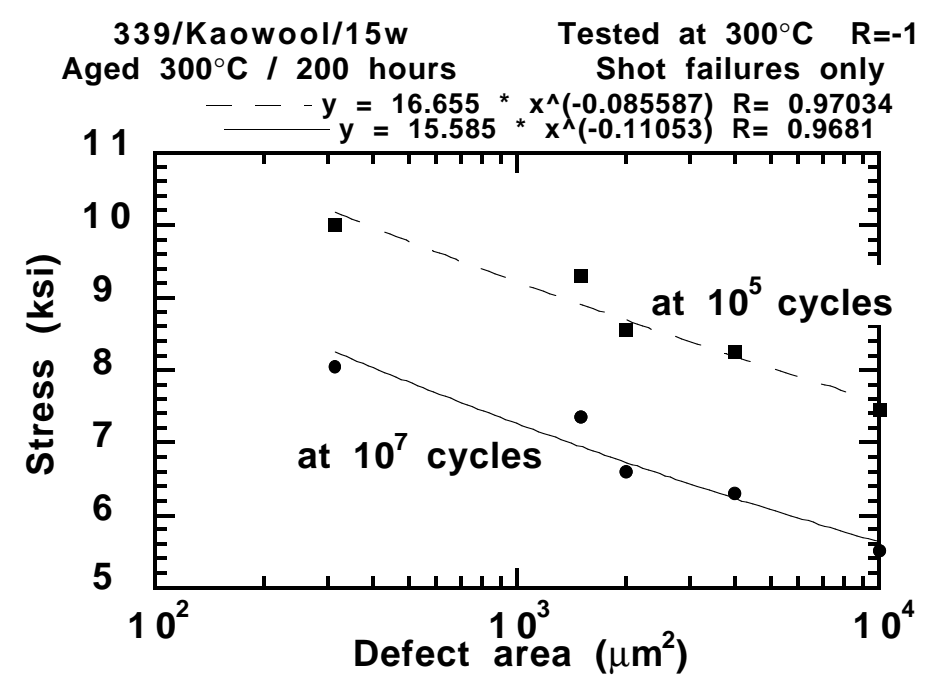

Fig. 27. Fatigue strength at $10^{5}$ and $10^{7}$ cycles versus defect area for 339/Kaowool/15w with failures due to shot particles at $300^{\circ} \mathrm{C}$. Lines represent a power law fit to the data.

Life versus local stress intensity and predicted life versus experimental data are shown in Figs. 28 and 29 for the ten data points suitable for this analysis. In both these figures, more scatter is observed between experimental data and the predictions of the model than observed for shot and porosity defects at $200^{\circ} \mathrm{C}$. An examination of the defect characteristics for the data in Figs. 28 and 29 reveals that four defects were not single, hollow shot particles. (In the analysis of shot particle failures at $200^{\circ} \mathrm{C}$, all data points resulted from failure origins at single, hollow shot particles). These data points with complex failure origins are listed in Table II with the characteristics of the failureinitiating defect. 


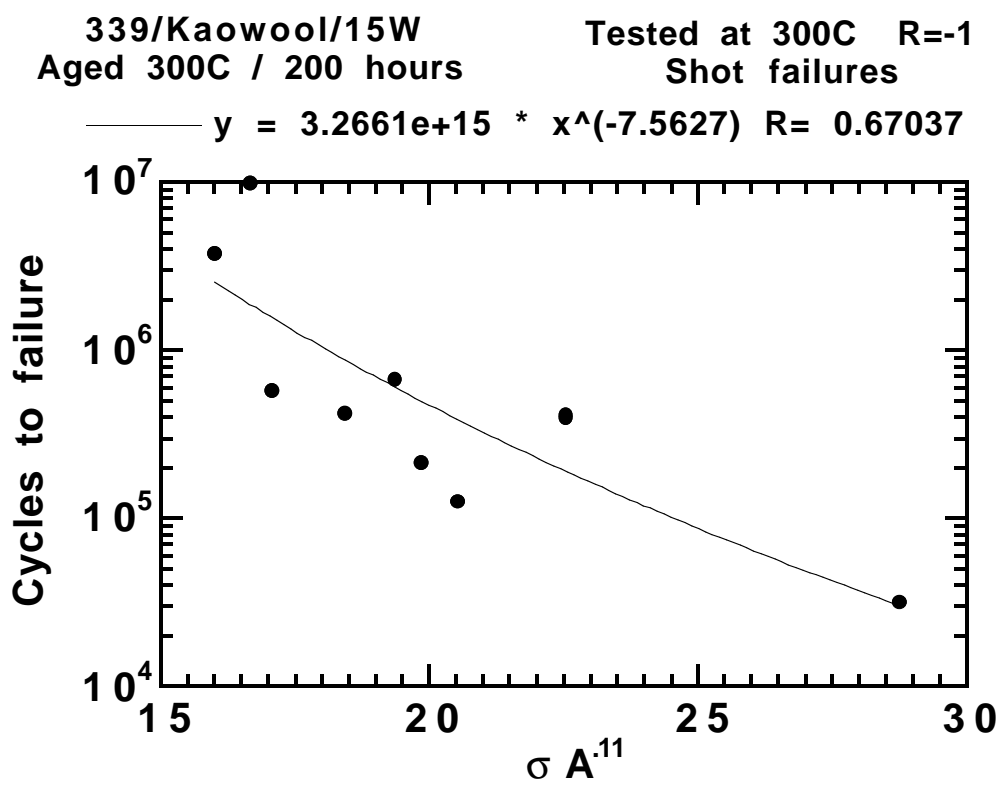

Fig. 28. Cycles to failure versus local stress intensity for shot failures at $300^{\circ} \mathrm{C}$. Local stress intensity $(\sigma A .11)$ is derived from the analysis in Fig. $25 . \quad$ Line represents a power law fit to the data.

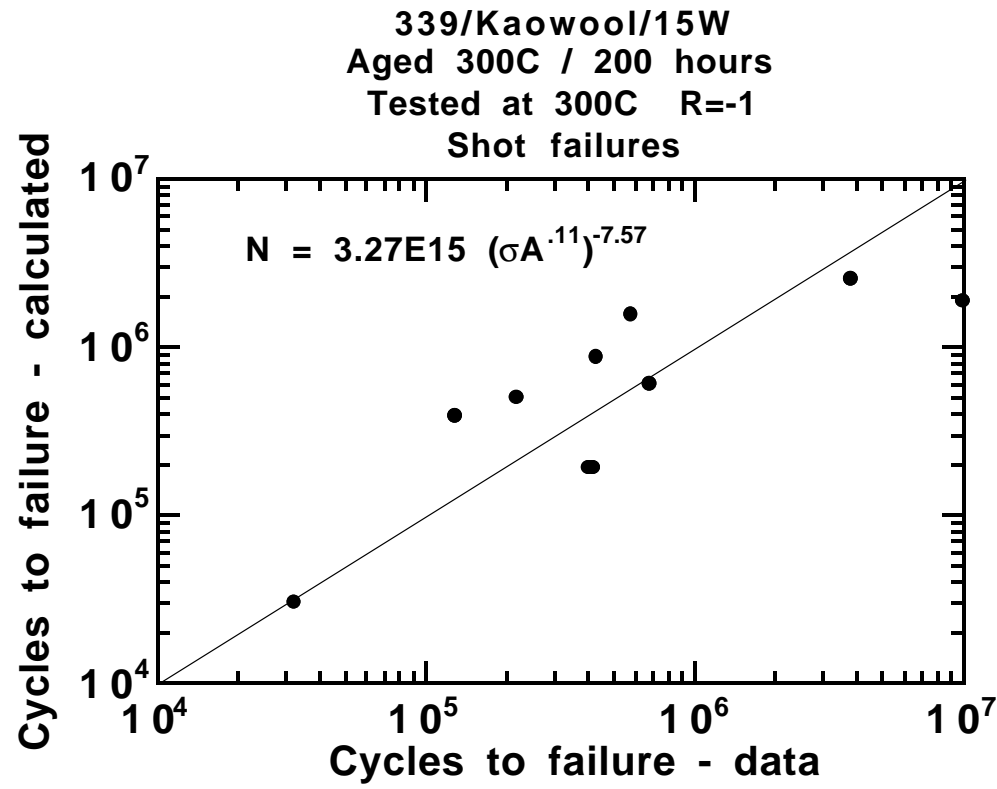

Fig. 29. Calculated number of cycles to failure versus experimental data. Calculations are based on the equation shown in the figure.

Table II

Defect Characteristics for Selected Data Points Tested at $300^{\circ} \mathrm{C}$

\begin{tabular}{|l|l|l|l|}
\hline Sample ID & Stress (ksi) & Cycles to failure & Defect Characteristics \\
\hline C111392-126-3 & 8.5 & $4.14 \mathrm{E} 5$ & Two particles together \\
\hline C111392-125-3 & 8.5 & $3.98 \mathrm{E} 5$ & Cluster of shot particles \\
\hline C111392-128-3 & 8 & $5.76 \mathrm{E} 5$ & $\begin{array}{l}\text { Difficult to quantify; } \\
\text { several shot particles }\end{array}$ \\
\hline C051194-23-3 & 12 & $3.20 \mathrm{E} 4$ & Filled shot \\
\hline
\end{tabular}


Figure 28 was re-plotted without the four data points shown in Table II and the results are shown in Fig. 30. Agreement with the proposed model is good; however, not as good as shown in Figs. 14 and 21 for the data at $200^{\circ} \mathrm{C}$. The calculated life, using the equation obtained in Fig. 30, is compared to experimental data in Fig. 31. The life equations for the 339/Kaowool/15w composite with the three defect type / testing temperature combinations are shown in Table III.

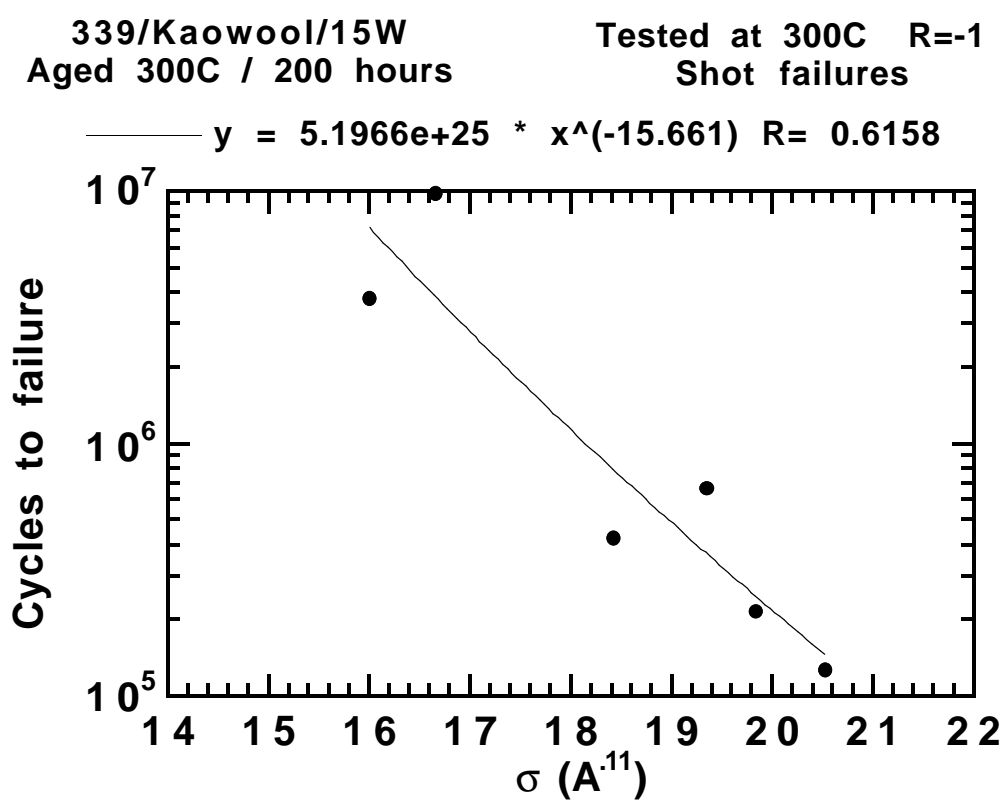

Fig. 30. Replot of data in Fig. 28 with suspect data points removed (see text).

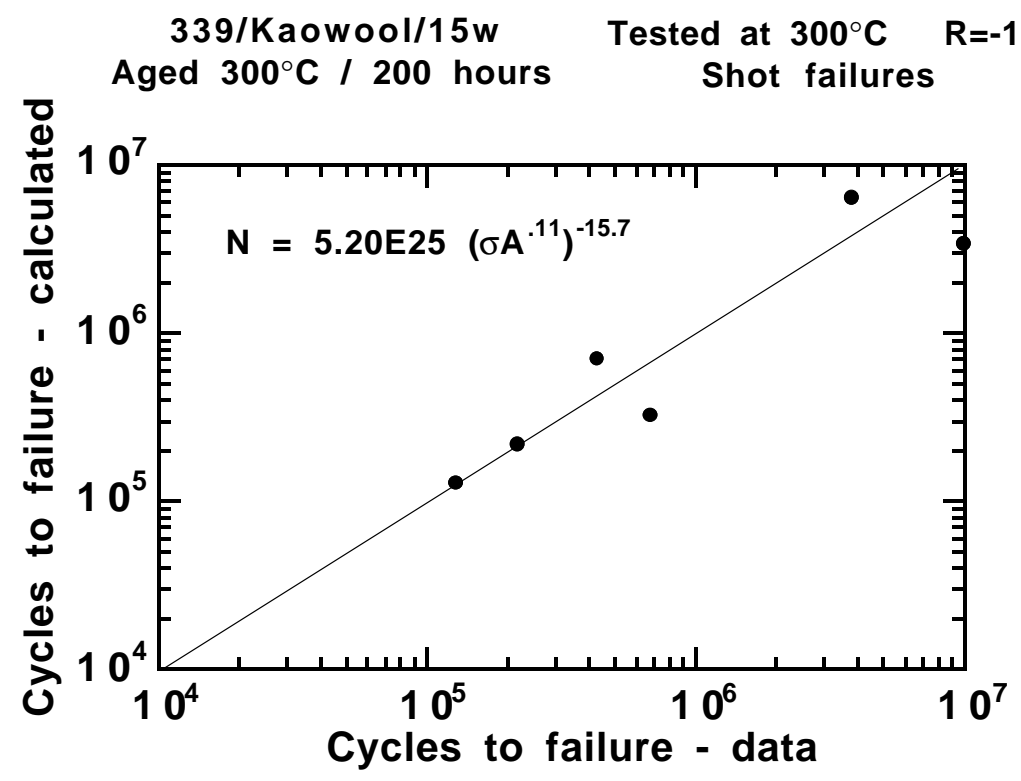

Fig. 31. Calculated number of cycles to failure versus experimental data. Calculations are based on the equation shown in the figure. 
Table III

Life Equations for 339/Kaowool/15w

with Different Defect Types and Testing Temperatures

\begin{tabular}{|l|l|l|}
\hline Defect type / testing temperature & Equation & Comments \\
\hline shot particles $/ 200^{\circ} \mathrm{C}$ & $\mathrm{N}=3.8310^{26}\left(\sigma \mathrm{A}^{115}\right)^{-12.9}$ & \\
\hline shot particles $/ 200^{\circ} \mathrm{C}$ & $\mathrm{N}=1.1710^{23}(\sigma \mathrm{A} \cdot 077)^{-12.7}$ & short defect data \\
\hline porosity $/ 200^{\circ} \mathrm{C}$ & $\mathrm{N}=7.2710^{28}\left(\sigma \mathrm{A}^{\cdot 072}\right)^{-17.2}$ & \\
\hline porosity $/ 200^{\circ} \mathrm{C}$ & $\mathrm{N}=2.8510^{29}(\sigma \mathrm{A} \cdot 041)^{-19.3}$ & short defect data \\
\hline shot particles $/ 300^{\circ} \mathrm{C}$ & $\mathrm{N}=3.2710^{15}\left(\sigma \mathrm{A}^{111}\right)^{-7.57}$ & \\
\hline
\end{tabular}

\section{MODEL PREDICTIONS}

The model proposed and examined in the previous sections can be used to predict the $\sigma-\mathrm{N}$ behavior for $339 / \mathrm{Kaowool} / 15 \mathrm{~W}$ composites assuming that failures originate at known defects. The predicted $\sigma-\mathrm{N}$ curves for failures resulting from spherical shot particles at $200^{\circ} \mathrm{C}$ are shown in Fig. 32 for hollow particles with diameters equal to 50 $\mu \mathrm{m}, 20 \mu \mathrm{m}$ and $10 \mu \mathrm{m}$. The results show that the endurance limit (stress at $10^{7}$ cycles) increases from $10.3 \mathrm{ksi}$ for defects with $50 \mu \mathrm{m}$ diameter, to $11.8 \mathrm{ksi}$ for defects with 20 $\mu \mathrm{m}$ diameter to $13.0 \mathrm{ksi}$ for defects with $10 \mu \mathrm{m}$ diameter. The analysis in Fig. 32 assumes, of course, that no other failure modes dominate. As the particles or other failure origins are made smaller and smaller, then other failure modes can intervene. In the limit, one would expect failures to originate in the matrix and the $\sigma-\mathrm{N}$ curve would be determined by microstructural features that control strength, such as the size and/or spacing of the particles and the inherent strength of the matrix (which can have its own reinforcing dispersion typical for aluminum alloys). An example of this transistion in failure modes (to a matrix dominated failure at small defect sizes) is provided in the next section for the case of $\mathrm{SiC}$ reinforced $\mathrm{Al}$.

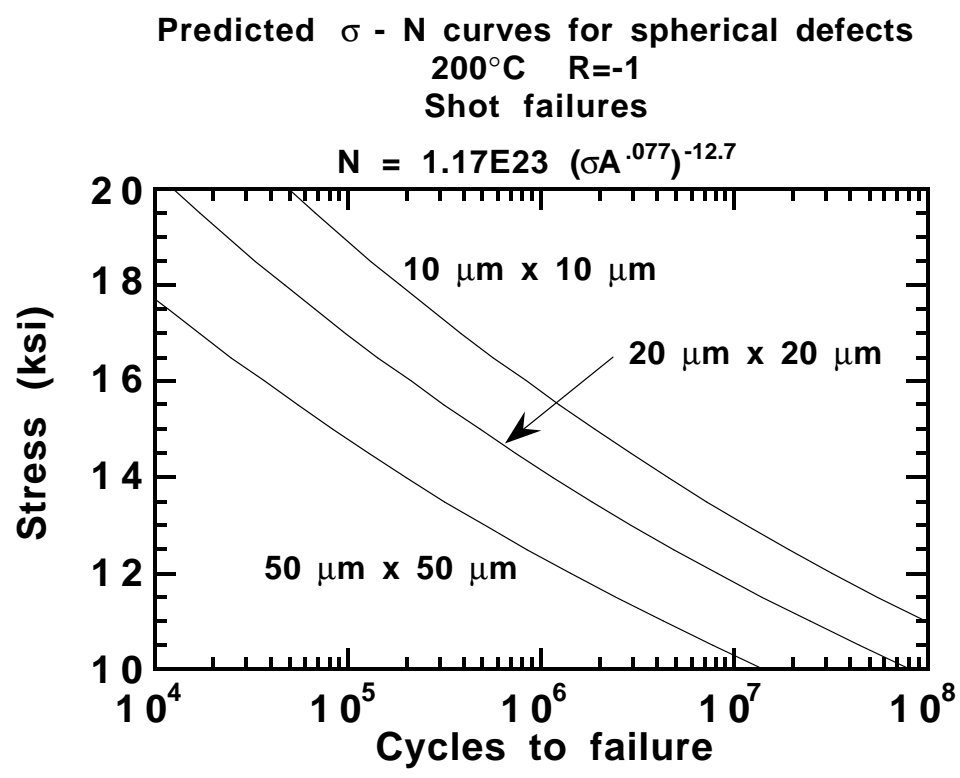

Fig. 32. Predicted $\sigma-N$ curves for failures due to spherical shot particles at $200^{\circ} \mathrm{C}$. 
The model can also be used to study the $\sigma-\mathrm{N}$ behavior, when competing failure modes are present, for MMCs containing both shot and porosity. Predicted $\sigma-\mathrm{N}$ curves are shown in Fig. 33 for failures due to spherical shot particles (solid curves) and porosity (dotted curves) at $200^{\circ} \mathrm{C}$. For both shot and porosity, two defect sizes were considered - $10 \mu \mathrm{m}$ diameter and $50 \mu \mathrm{m}$ diameter. Figure 33 shows that for $10 \mu \mathrm{m}$ size defects, porosity is more damaging than shot. However, the difference between them decreses with decreasing stress and the two $\sigma-\mathrm{N}$ curves converge at $10^{8}$ cycles. For the $50 \mu \mathrm{m}$ diameter defects, porosity is more damaging than shot in the high stress / low life regime and shot is more damaging than porosity in the low stress / high life regime. The transistion from porosity-dominated failures to shot-dominated failures occurs at 2 $10^{6}$ cycles. As discussed previously, for large defects at comparable size, porosity is less damaging than shot. This conclusion is supported by the results in Fig. 33 .

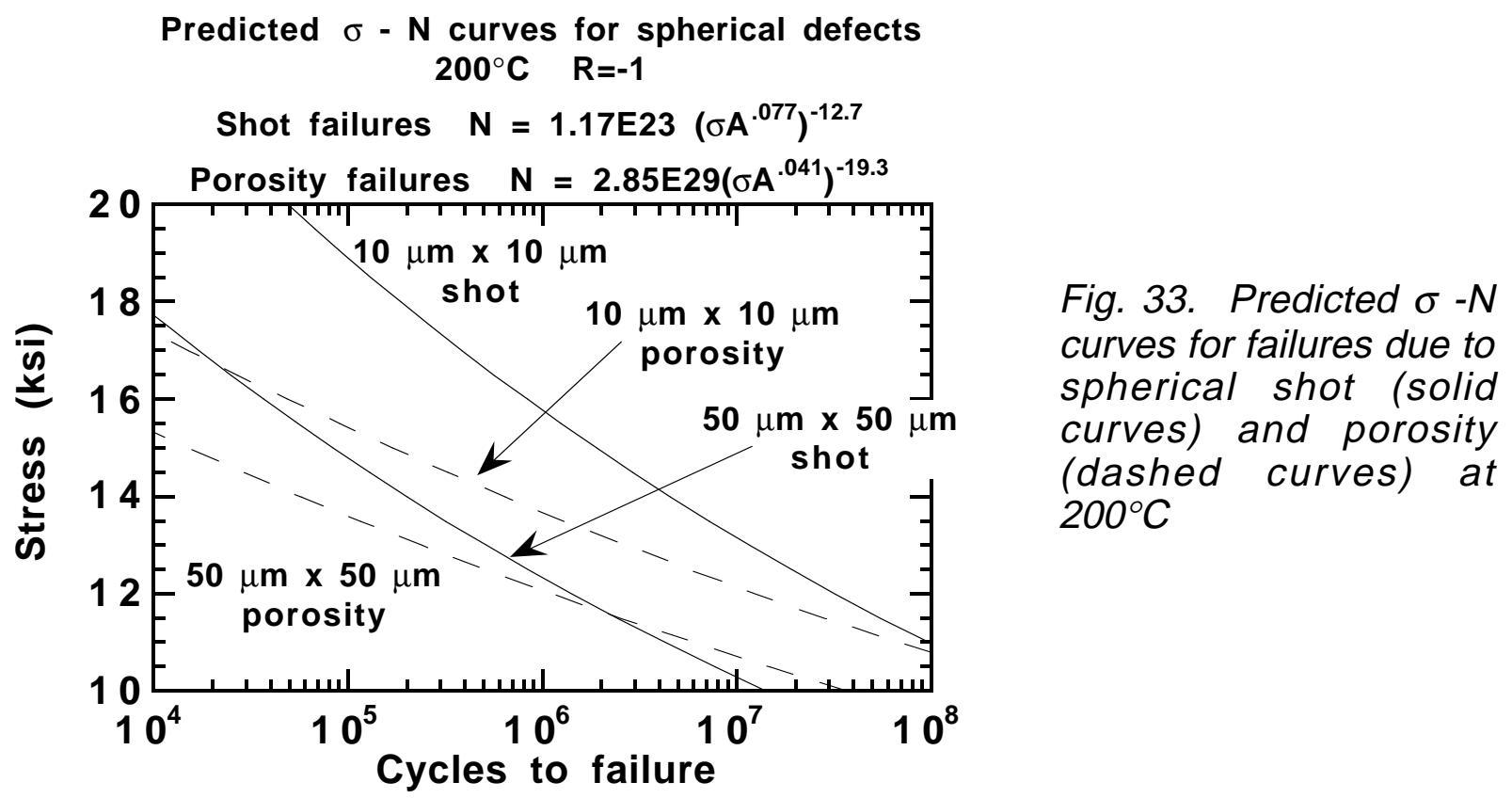

\section{ANALYSIS OF DATA FROM THE LITERATURE}

The literature contains very little data that can be used to assess the influence of defect size on fatigue life in MMCs. The one notable exception is from the work of Holcomb [9] on the $2124 / \mathrm{SiC} / 20 \mathrm{p}$ composite. This material was processed from metal powders that were blended with particle powders containing three different average sizes - $3 \mu \mathrm{m}, 17$ $\mu \mathrm{m}$ and $35 \mu \mathrm{m}$. The powders were then consolidated, extruded and T6 treated (heat treated for $10 \mathrm{hrs}$. at $175^{\circ} \mathrm{C}$ ). The samples were then fatigue tested under stress control at room temperature using smooth bar samples and $R=-1$. In the high cycle fatigue regime, failures often originated from fracture of the $\mathrm{SiC}$ particles. For the 17 and 35 $\mu \mathrm{m}$ particle samples, fatigue failures initiated predominatly from fractured $\mathrm{SiC}$ particles. For the $3 \mu \mathrm{m}$ particle samples, fatigue failures were either associated with particle 
fracture or failure in the matrix. Thus the $3 \mu \mathrm{m}$ material appears to have a particle size in which a transistion is being made from particle-initiated failure (at large particle sizes) to matrix initiated failure (at small particle sizes).

The fatigue strength at $10^{7}$ cycles for the $2124 / \mathrm{SiC} / 20 \mathrm{p}$ composite (obtained from ref. 9) was then plotted versus defect area assuming failure originated from the SiC particles. The results are shown in Fig. 34. The area exponent was found to be 11.8, which is comparable to the values found for shot particles in the present study.

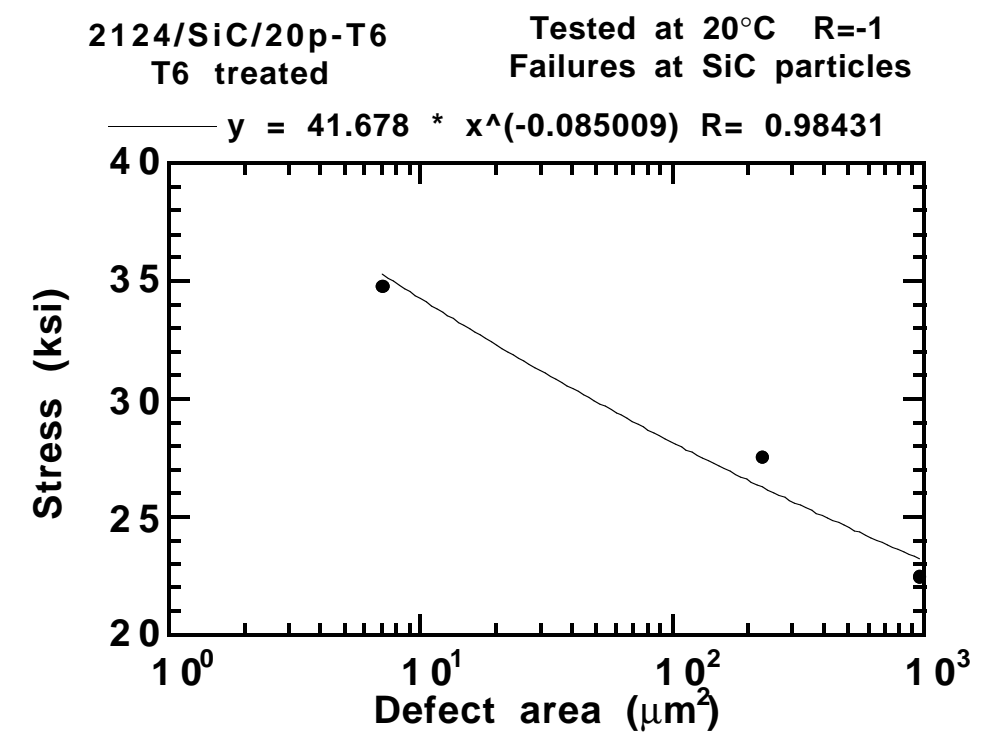

Fig. 34. Fatigue strength at $10^{7}$ cycles versus defect area for 2124/SiC/20p-T6 at $20^{\circ} \mathrm{C}$. Fatigue failures are assumed to initiate at SiC particles. Line represents a power law fit to the data. Fatigue data is from ref. 9.

\section{SUMMARY AND CONCLUSIONS}

The high cycle fatigue behavior has been studied for MMCs based on the aluminum 339 casting alloy with Kaowool reinforcement. This report describes results and data analysis for the 339/Kaowool/15w composite. The project involved testing 130 $339 / \mathrm{Kaowool} / 15 \mathrm{w}$ samples at different temperatures from room temperature to $300^{\circ} \mathrm{C}$. Experiments were conducted on samples that had received different annealing treatments before testing. The defects responsible for fatigue failure were characterized. In the high cycle fatigue regime, the number of cycles to failure was found to vary as a power law function of the stress. Sufficient data were available for failures originating from three different defect / testing temperature combinations to quantify the relationship between defect type, defect size and cycling stress on resulting fatigue life. The three defect type / testing temperature combinations were shot particles at $200^{\circ} \mathrm{C}$, porosity at $200^{\circ} \mathrm{C}$ and shot particles at $300^{\circ} \mathrm{C}$. For all three combinations, the fatigue strengths at $10^{5}$ and $10^{7}$ cycles were found to follow a phenomenological relationship involving the stress and the cross-sectional area of the defect (shown as Equation (1)). The analysis follows a model derived by Murakami and Endo, in which the local stress intensity produced by a defect is related to the cross- 
sectional area of the defect. The area exponent in Equation (1) was larger than expected from continuum mechanics calculations, indicating the local stress intensity was not as large as predicted by theory. This difference was attributed to a size scale effect. In addition for porosity failures, ligaments span the defect region and thus reduce the local stress intensity. A new model was proposed to predict the life of samples as a function of stress and defect characteristics (size and type). For the three data sets described above, the model could predict the life of the three different defect/temperature combinations described above to better than half a decade. Extension of the model to defect sizes smaller than observed in the current experiments provides insight into fatigue limits and $\sigma-\mathrm{N}$ behavior that might be expected with cleaner composites. For spherical hollow shot particles, the endurance limit (stress at $10^{7}$ cycles) increases from $10.3 \mathrm{ksi}$ for defects with $50 \mu \mathrm{m}$ diameter, to $11.8 \mathrm{ksi}$ for defects with $20 \mu \mathrm{m}$ diameter to $13.0 \mathrm{ksi}$ for defects with $10 \mu \mathrm{m}$ diameter.

\section{ACKNOWLEDGEMENTS}

The authors acknowledge the work of Dave Hiromoto in mechanical testing and Jim Ferreira and Ed Sedillo for metallography and SEM fractography. This work was performed under the auspices of the U.S. Department of Energy by Lawrence Livermore National Laboratory under contract No. W-7405-Eng-48.

\section{REFERENCES}

1. D.R. Lesuer, T. G. Nieh, and C. K. Syn, "Fatigue of Metal Matrix Composites", First year summary report, LLNL, 1994.

2. W.J. Baxter, presented at CRADA meeting, Nov. 16, 1993.

3. T.G. Nieh, D. R. Lesuer, and C. K. Syn, Scripta Metallurgica et Materialia, 1995, 32, 707-712.

4. Y. Murakami and M. Endo, International Journal of Fatigue, 1994, 16, 163 - 182.

5. Y. Murakami and M. Endo, Engineering Fracture Mechanics, 1983, 17, 1 -15.

6. H. Nisitani and K. Kawano, Transactions Japan Society of Mechanical Engineers, 1971, 37, 1492-1496.

7. Y. Murakami and T. Endo, in "The Effects of Small Defects on the Fatigue Strength of Hard Steels", in Proceedings of the International Conference on Fatigue '81, Warweick University, 1981, 431-440.

8. S. Suresh, Fatigue of Materials, Cambridge University Press, 1991.

9. S.W. Holcomb, "The Effects of Particle Size on High Cycle Fatigue Properties of Silicon Carbide Reinforced 2124 Aluminum", M.S. Thesis, University of Southern California, 1992. 


\begin{tabular}{|c|c|c|c|c|c|c|c|c|c|c|}
\hline \multirow[t]{2}{*}{ Material } & $\begin{array}{c}\text { Temp } \\
(\mathrm{oC})\end{array}$ & $\begin{array}{l}\text { Sample } \\
\text { ID \& \# }\end{array}$ & $\begin{array}{c}\text { Stress } \\
(\mathrm{ksi})\end{array}$ & \#Cycles & $\begin{array}{l}\text { Initiation } \\
\text { Site }\end{array}$ & $\begin{array}{l}\text { Defect } \\
\text { Shape }\end{array}$ & $\begin{array}{c}\text { Defect Size } \\
X \times Y(\mu \mathrm{m})\end{array}$ & $\begin{array}{c}\text { Defect } \\
\text { Depth } \\
(\mu \mathrm{m})\end{array}$ & $\begin{array}{c}\text { Fatigue } \\
\begin{array}{c}\text { Zone Size } \\
(\mathrm{mm})\end{array}\end{array}$ & Comments \\
\hline & & & & \multicolumn{5}{|c|}{ Unrentarorco Matrix Aloy } & & \\
\hline 339 & 20 & C120292-39-4 & 15 & $2.20 \mathrm{E}+04$ & 1 & Elong. & $1000 \times 2000$ & $0-800$ & 1.9 & Unaged. Al rich/EDAX. \\
\hline 339 & 20 & C120292-33-3 & 14 & $7.34 \mathrm{E}+05$ & $\mathrm{P}$ & Irreg. & $540 \times 540$ & $0-520$ & 2.3 & Unaged. \\
\hline 339 & 20 & C120292-67-5 & 14.5 & $1.20 \mathrm{E}+06$ & $P$ & Irreg. & $300 \times 100$ & 0 & 1 & Unaged. EDAX. \\
\hline 339 & 20 & C120392-33-4 & 13.5 & $1.80 \mathrm{E}+06$ & $\mathbf{I}$ & Elong & $70 \times 200$ & $0-180$ & 1.8 & Unaged. EDAX. \\
\hline \multirow[t]{2}{*}{339} & 20 & C120392-29-3 & 13 & $\begin{array}{c}1.49 E+07 \\
\text { Runout }\end{array}$ & & & & & & \\
\hline & & & & & \multicolumn{3}{|c|}{ 7\% KaOWOOI } & & & \\
\hline $339 / \mathrm{Kao} / 7$ & 20 & C111392-31-1 & 31 & $4.00 \mathrm{E}+02$ & $S$ & Elong. & $50 \times 150$ & $0-120$ & Unmeas. & Unaged. 1 fract. surface examined. \\
\hline $339 / \mathrm{Kao} / 7$ & 20 & C111392-31-3 & 20 & $4.10 E+04$ & $\mathrm{P} / \mathrm{S}$ & Elong & $\begin{array}{l}100 \times 15 \\
20 \times 100\end{array}$ & 0 & Unmeas. & Unaged. Shot on 1 surface, porosity on the other. \\
\hline $339 / \mathrm{KaO} / 7$ & 20 & C111392-32-4 & 18.5 & $1.39 \mathrm{E}+05$ & $\mathbf{S}$ & Oval & $50 \times 70$ & $0-70$ & 1.5 & Unaged. 2 fract. surf. exam. EDAX both Surf. \\
\hline $339 / \mathrm{Kao} / 7$ & 20 & C111392-32-5 & 17 & $5.00 \mathrm{E}+05$ & $\mathrm{~S} / \mathrm{P}$ & Sickle & 300 & 0 & Unmeas. & Unaged. 2 fract. surfaces examined. \\
\hline $339 / \mathrm{KaO} / 7$ & 20 & C111392-34-4 & 17 & $9.87 \mathrm{E}+06$ & $\mathrm{~S}$ & Rctngl. & $60 \times 45$ & $0-45$ & 1.5 & Unaged. EDAX one side. \\
\hline $339 / \mathrm{Kao} / 7$ & 20 & C111392-31-2 & 15 & $\begin{array}{l}1.01 \mathrm{E}+07 \\
\text { Runout }\end{array}$ & & & & & & Unaged. \\
\hline $339 / \mathrm{KaO} / 7$ & 300 & C111392-41-1 & 8.5 & $9.95 \mathrm{E}+04$ & $\mathrm{~S}$ & $\begin{array}{c}2 \text { elong. } \\
\text { touch. }\end{array}$ & $\begin{array}{c}65 \times 35 \\
15 \\
\end{array}$ & $0-35$ & Unmeas. & $\begin{array}{l}\text { 300C/200h preaged. } 2 \text { touching elong. shots. } 2 \text { fract. } \\
\text { surf's exam. EDAX. }\end{array}$ \\
\hline $339 / \mathrm{Kao} / 7$ & 300 & C111392-45-1 & 8 & $3.80 \mathrm{E}+05$ & $\mathrm{~S} / \mathrm{S}$ & $\begin{array}{l}\text { Spher. } \\
\text { Elong. }\end{array}$ & $\begin{array}{c}40 \\
100 \times 45 \\
\end{array}$ & $0-45$ & 1.5 & $300 \mathrm{C} / 200 \mathrm{~h}$ EDAX. A 2nd interpretation. \\
\hline $339 / \mathrm{Kao} / 7$ & 300 & C111392-54-1 & 7.5 & $4.02 E+05$ & $\mathrm{~S} / \mathrm{P}$ & $\begin{array}{l}\text { Spher. } \\
\text { Irreg. }\end{array}$ & $\begin{array}{c}25 \times 45 \\
45 \\
\end{array}$ & $0-35$ & 1.5 & $300 \mathrm{C} / 200 \mathrm{~h} 2$ fract. surfaces examined. EDAX done. \\
\hline $339 / \mathrm{Kao} / 7$ & 300 & C111392-44-1 & 7 & $1.25 \mathrm{E}+06$ & $\mathrm{~S}$ & Spher. & 50 & $0-50$ & 1.5 & $300 \mathrm{C} / 200 \mathrm{~h}$ \\
\hline $339 / \mathrm{Kao} / 7$ & 300 & $C 111392-40-1$ & 6.75 & $10 \mathrm{M}$ & $\mathrm{S}$ & Spher. & $30 \times 50$ & & Unmeas. & $\begin{array}{l}300 \mathrm{C} / 200 \mathrm{~h} 2 \text { fract. surf. } \mathrm{xm} \text { 'ed. Origin difficult to } \\
\text { establish. }\end{array}$ \\
\hline $339 / \mathrm{KaO} / 7$ & 300 & C111392-55-1 & 6.5 & $\begin{array}{c}\text { 10M+ } \\
\text { Runout }\end{array}$ & & & & & & \\
\hline & & & & & & & & & & \\
\hline & & & & & & & & & & \\
\hline
\end{tabular}




\begin{tabular}{|c|c|c|c|c|c|c|c|c|c|c|}
\hline Material & $\begin{array}{c}\text { Temp } \\
(\mathrm{oC})\end{array}$ & $\begin{array}{l}\text { Sample } \\
\text { ID \&\# }\end{array}$ & $\begin{array}{c}\text { Stress } \\
\text { (ksi) }\end{array}$ & \#Cycles & $\begin{array}{l}\text { Initiation } \\
\text { Site }\end{array}$ & $\begin{array}{l}\text { Defect } \\
\text { Shape }\end{array}$ & $\mid \begin{array}{c}\text { Defect Size } \\
X X Y(\mu \mathrm{m})\end{array}$ & $\begin{array}{c}\text { Defect } \\
\text { Depth } \\
(\mu \mathrm{m})\end{array}$ & $\begin{array}{c}\text { Fatigue } \\
\text { Zone Size } \\
(\mathrm{mm})\end{array}$ & Comments \\
\hline & & & & & \multicolumn{3}{|c|}{$15 \%$ KaOwool } & & & \\
\hline 339/Kao/15 & 20 & C100292-30-7 & 17 & $8.82 E+05$ & 1 & Elong & $150 \times 300$ & 50 & & Unaged. CAT scan. before testing. Failed in grip. \\
\hline $339 / \mathrm{Kao} / 15$ & 20 & C111392-116-2 & 17 & $8.57 E+04$ & $S$ & Spher. & $40 \times 50$ & 2 & 1.5 & Unaged.CAT scan. $(200 \mu \mathrm{m}$ resol'n). \\
\hline $339 / \mathrm{KaO} / 15$ & 20 & C111392-117-1 & 16 & $3.60 \mathrm{E}+05$ & $\mathrm{~S}$ & Sickle & $30 \times 150$ & 60 & 1.4 & Unaged. CAT (50 \& 200 $\mu \mathrm{m}$ resol'n). \\
\hline $339 / \mathrm{KaO} / 15$ & 20 & C111392-126-4 & 16 & 3.27E+04 & $P$ & Irreg. & $60 \times 80$ & $0-80$ & 1.4 & $300^{\circ} \mathrm{C} / 200 \mathrm{hrs}$ preaged. \\
\hline $339 / \mathrm{KaO} / 15$ & 20 & C111392-130-1 & 15 & $1.86 \mathrm{E}+06$ & $\mathrm{~S} / \mathrm{P}$ & $\begin{array}{l}\text { Spher. } \\
\text { Irreg. }\end{array}$ & $\begin{array}{c}50 \\
40 \times 130 \\
\end{array}$ & $\begin{array}{c}60 / \\
30-100 \\
\end{array}$ & 1.2 & Unaged. Shot at the tip of an oblique chain of porosity. \\
\hline 339/Kao/15 & 20 & C111392-116-2 & 15 & $3.92 E+05$ & $P$ & Irreg. & $260 \times 20$ & $30-170$ & 1.6 & \\
\hline $339 / \mathrm{KaO} / 15$ & 20 & C111392-120-2 & 15 & & & & & & & $\begin{array}{l}\text { Unaged. CAT ( } 50 \& 200 \mu \mathrm{m} \text { resol'n). Failed in grip } \\
\text { before testing. }\end{array}$ \\
\hline $339 / \mathrm{KaO} / 15$ & 300 & C100292-36-3 & 8.5 & $3.78 \mathrm{E}+06$ & S & $\begin{array}{l}\text { Cluster } \\
\text { of shots }\end{array}$ & $<20$ & 50 & 1.8 & $300 \mathrm{C} / 200 \mathrm{~h}$ preaged. CAT scan. $50 \mu \mathrm{m}$ resol'n \\
\hline $339 / \mathrm{Kao} / 15$ & 300 & C111392-128-4 & 8.5 & $6.72 \mathrm{E}+05$ & $\mathrm{~S}$ & Spher. & $50 \times 45$ & $0-45$ & 1.9 & $300 \mathrm{C} / 200 \mathrm{~h}$ \\
\hline $339 / \mathrm{Kao} / 15$ & 300 & C111392-126-3 & 8.5 & 4.14E+05 & $S$ & Bagel & $60 \times 150$ & $0-60$ & 1.5 & $300 \mathrm{C} / 200 \mathrm{~h}$ preaged. Bagel-shaped \\
\hline $339 / \mathrm{KaO} / 15$ & 300 & C111392-128-7 & 8.5 & 2.61E+05 & $\mathrm{P}$ & $\begin{array}{c}\text { Two } \\
\text { chains }\end{array}$ & $400 \times 150$ & $10-140$ & 1.4 & $\begin{array}{l}300 \mathrm{C} / 200 \mathrm{~h} \text { preaged. Two connected subsurface } \\
\text { chains }\end{array}$ \\
\hline 339/Kao/15 & 300 & C111392-125-3 & 8.5 & $3.98 \mathrm{E}+05$ & $\mathrm{~s}$ & Spher. & $120 \times 75$ & 0 & 1.2 & $300 \mathrm{C} / 200 \mathrm{~h}$ preaged. Cluster of small shots \\
\hline $339 / \mathrm{KaO} / 15$ & 300 & C111392-114-2 & 8.5 & $7.31 E+04$ & $\mathbf{P}$ & $\begin{array}{l}\text { Cluster } \\
\text { of Irreg. }\end{array}$ & $250 \times 250$ & 50 & 1.2 & $\begin{array}{l}300 \mathrm{C} / 200 \mathrm{~h} \text { preaged. Cluster of six small porosities of } \\
\text { about } 50 \times 30 \text {. }\end{array}$ \\
\hline $339 / \mathrm{KaO} / 15$ & 300 & C111392-131-4 & 8 & $2.49 \mathrm{E}+06$ & 1 & Irreg. & $40 \times 15$ & 0 & 1.8 & 300C/200h preaged. Sp. w/Baxter \\
\hline $339 / \mathrm{Kao} / 15$ & 300 & C111392-128-3 & 8 & $5.76 \mathrm{E}+05$ & s & Elong. & $25 \times 50$ & $0-50$ & 1.3 & $300 \mathrm{C} / 200 \mathrm{~h}$ preaged. Several small shots. \\
\hline $339 / \mathrm{KaO} / 15$ & 300 & C111392-120-1 & 8 & 4.25E+05 & $\mathrm{S} / \mathrm{S}$ & $\begin{array}{l}\text { Spher. } \\
\text { Spher. }\end{array}$ & $\begin{array}{l}50 \\
80 \\
\end{array}$ & $\begin{array}{l}250 \\
>250 \\
\end{array}$ & $\begin{array}{c}\mathrm{Im}- \\
\text { meas'ble }\end{array}$ & $\begin{array}{l}300 \mathrm{C} / 200 \mathrm{~h} \text { preaged . CAT scan. } 50 \mu \mathrm{m} \text { resol' Shot } \\
\text { possible origin. }\end{array}$ \\
\hline $339 / \mathrm{Koa} / 15$ & 300 & C111392-114-3 & 8 & $2.16 \mathrm{E}+05$ & S & Spher. & 70 & $0-60$ & 1.7 & $300 \mathrm{C} / 200 \mathrm{~h}$ preaged. \\
\hline $339 / \mathrm{Koa} / 15$ & 300 & C111392-129-7 & 8 & $1.84 \mathrm{E}+05$ & $P$ & Irreg. & $40 \times 300$ & $20-200$ & 1.7 & $300 \mathrm{C} / 200 \mathrm{~h}$ preaged. Multiple long-chain \\
\hline 339/Koa/15 & 300 & C111392-128-6 & 8 & $1.66 \mathrm{E}+05$ & $P$ & Irreg. & $30 \times 150$ & $30-150$ & 1.6 & $300 \mathrm{C} / 200 \mathrm{~h}$ preaged. Two straight chains. \\
\hline $339 / \mathrm{Kao} / 15$ & 300 & C111392-116-1 & 8 & & $\mathrm{P}$ & Irreg. & & & & Failed at start. \\
\hline $339 / \mathrm{KaO} / 15$ & 300 & C110292-36-2 & 7.5 & $10 \mathrm{MC}+$ & Runout & - & - & - & - & $300 \mathrm{C} / 200 \mathrm{~h}$ preaged. CAT scan. (50 $\mu \mathrm{m}$ resol'n) \\
\hline $339 / \mathrm{KaO} / 15$ & 300 & C111392-129-3 & 7.5 & $9.87 \mathrm{E}+06$ & $s$ & Spher. & $20 \times 90$ & 100 & 1.6 & $300 \mathrm{C} / 200 \mathrm{~h}$ preaged. Shot partially hollow. \\
\hline $339 / \mathrm{Koa} / 15$ & 300 & C111392-129-4 & 7.5 & $4.34 \mathrm{E}+06$ & 1 & Irreg. & $20 \times 240$ & $0-60$ & 1.7 & $300 \mathrm{C} / 200 \mathrm{~h}$ preaged. Elliptic chain of incl. \& shots \\
\hline
\end{tabular}




\begin{tabular}{|c|c|c|c|c|c|c|c|c|c|c|}
\hline Material & $\begin{array}{r}\text { Temp } \\
(\mathrm{OC})\end{array}$ & $\begin{array}{l}\text { Sample } \\
\text { ID \&\# }\end{array}$ & $\begin{array}{c}\text { Stress } \\
(\mathrm{ksi})\end{array}$ & \#Cycles & $\begin{array}{l}\text { Initiation } \\
\text { Site }\end{array}$ & $\begin{array}{l}\text { Defect } \\
\text { Shape }\end{array}$ & $\begin{array}{c}\text { Defect Size } \\
\mathrm{XxY}(\mu \mathrm{m})\end{array}$ & $\begin{array}{l}\text { Defect } \\
\text { Depth } \\
(\mu \mathrm{m})\end{array}$ & $\begin{array}{c}\text { Fatigue } \\
\text { Zone Size } \\
(\mathrm{mm})\end{array}$ & Comments \\
\hline $339 / \mathrm{KaO} / 15$ & 300 & C111392-131-1 & 7.5 & $2.06 \mathrm{E}+06$ & $P$ & Irreg. & 120 & 0 & 1.4 & $\begin{array}{l}300 \mathrm{C} / 200 \mathrm{~h} \text { preaged. CAT Scan. }(50 \mu \mathrm{m} \text { resol'n). } \\
\text { Maybe unpre-annealed }\end{array}$ \\
\hline 339/Kao/15 & 300 & C111392-131-3 & 7.5 & $6.25 \mathrm{E}+05$ & $\mathrm{P}$ & Irreg. & 450 & 0 & 1.3 & $300 \mathrm{C} / 200 \mathrm{~h}$ preaged. CAT scanned $50 \mu \mathrm{m}$ resol'n. \\
\hline $339 / \mathrm{KaO} / 15$ & 300 & C111392-118-2 & 7.5 & $1.27 \mathrm{E}+05$ & $\begin{array}{c}S+P \\
S\end{array}$ & $\begin{array}{l}\text { Irreg. } \\
\text { Spher. }\end{array}$ & $\begin{array}{c}75 \times 160 \\
70\end{array}$ & $\begin{array}{c}30-190 \\
1000\end{array}$ & $1.0 ?$ & $300 \mathrm{C} / 200 \mathrm{~h}$ preaged. CAT Scan. (50 $\mu \mathrm{m}$ resol'n) \\
\hline $339 / \mathrm{Koa} / 15$ & 200 & C111392-127-4 & 13 & $3.46 \mathrm{E}+05$ & $\mathrm{~S}$ & Thumb & $40 \times 100$ & $0-100$ & 1.1 & $200 \mathrm{C} / 200 \mathrm{~h}$ preaged. High aspect ratio. Sp. w/Baxter \\
\hline $339 / \mathrm{Koa} / 15$ & 200 & C111392-124-3 & 13 & $2.44 \mathrm{E}+05$ & $\mathrm{~s}$ & Peach & $30 \times 70$ & $0-60$ & 1 & $200 \mathrm{C} / 200 \mathrm{~h}$ preaged. Partially filled. \\
\hline $339 / \mathrm{KaO} / 15$ & 200 & C111392-125-4 & 13 & $2.27 E+05$ & $\mathrm{~s}$ & Shper. & $80 \times 40$ & $0-40$ & 1 & 200C/200h preaged. Sp. w/Baxter \\
\hline $339 / \mathrm{Kao} / 15$ & 200 & C111392-124-4 & 13 & $1.32 E+05$ & $\mathrm{P}$ & Irreg. & $70 \times 50$ & $0-70$ & 1 & $200 \mathrm{C} / 200 \mathrm{~h}$ preaged. \\
\hline $339 / \mathrm{Kao} / 15$ & 200 & C111392-118-1 & 13 & $4.98 \mathrm{E}+04$ & $\mathrm{P}$ & Irreg. & $150 \times 200$ & $0-200$ & 1 & $200 \mathrm{C} / 200 \mathrm{~h}$ preaged. CAT scanned. \\
\hline $339 / \mathrm{Koa} / 15$ & 200 & C111392-118-3 & 12 & $1.97 \mathrm{E}+06$ & $\mathrm{~s}$ & Ellips. & $70 \times 40$ & 0 & 1 & $200 \mathrm{C} / 200 \mathrm{~h}$ preaged. Sp. w/Baxter \\
\hline $339 / \mathrm{Koa} / 15$ & 200 & C111392-128-5 & 12 & 4.14E+05 & $P$ & Irreg & $80 \times 200$ & $0-80$ & 1.4 & $\begin{array}{l}200 \mathrm{C} / 200 \mathrm{~h} \text { preaged. ORNL sp., multiple sites. } 4 \\
\text { additinal clusters nearby. }\end{array}$ \\
\hline $339 / \mathrm{KaO} / 15$ & 200 & C111392-120-4 & 12 & $3.94 \mathrm{E}+05$ & $\mathrm{P} / \mathrm{S}$ & Irreg. & $\begin{array}{l}70 \times 90 / \\
60 \times 35 \\
\end{array}$ & $0-70 / 30$ & 1.2 & $200 \mathrm{C} / 200 \mathrm{~h}$ preaged. Two sites $300 \mu \mathrm{m}$ apart. \\
\hline $339 / \mathrm{KaO} / 15$ & 200 & C111392-131-2 & 12 & $2.97 E+05$ & $\mathrm{~s}$ & Spher. & $80 \times 100$ & $10-110$ & 1.2 & $200 \mathrm{C} / 200 \mathrm{~h}$ preaged. Sp. w/Baxter \\
\hline $339 / \mathrm{KaO} / 15$ & 200 & C111392-120-3 & 12 & $2.91 E+04$ & $\mathrm{P}$ & Irreg. & $100 \times 350$ & $10-100$ & 1 & $200 \mathrm{C} / 200 \mathrm{~h}$ preaged. \\
\hline $339 / \mathrm{KaO} / 15$ & 200 & C111392-123-3 & 11 & $4.72 \mathrm{E}+06$ & $\mathrm{~s}$ & Apple & 80 & 0 & 1.8 & $200 \mathrm{C} / 200 \mathrm{~h}$ preaged. Shot fractured in halves. \\
\hline $339 / \mathrm{Kao} / 15$ & 200 & C111392-118-4 & 11 & $4.08 E+06$ & $\begin{array}{l}\mathrm{S} \\
\mathrm{P}\end{array}$ & $\begin{array}{l}\text { Irreg. } \\
\text { Irreg. }\end{array}$ & $\begin{array}{l}35 \times 50 / \\
100 \times 30\end{array}$ & $\begin{array}{r}10-25 / \\
50-100 \\
\end{array}$ & 1.8 & $\begin{array}{l}200 \mathrm{C} / 200 \mathrm{~h} \text { preaged. Shot and long fibers. /Oblique } \\
\text { porosity chain. }\end{array}$ \\
\hline $339 / \mathrm{KaO} / 15$ & 200 & C111392-114-1 & 11 & $2.50 \mathrm{E}+06$ & $P$ & Irreg. & $130 \times 80$ & $0-80$ & 1.2 & $200 \mathrm{C} / 200 \mathrm{~h}$ preaged. Interconnected porosity. \\
\hline $339 / \mathrm{KaO} / 15$ & 200 & C111392-114-4 & 10 & $1.08 \mathrm{E}+07$ & $\mathbf{P}$ & Irreg. & $90 \times 140$ & $0-90$ & 1.6 & $200 \mathrm{C} / 200 \mathrm{~h}$ preaged. C-shaped chain of porosity \\
\hline $339 / \mathrm{Kao} / 15$ & 200 & C111392-117-2 & 10 & $4.64 \mathrm{E}+06$ & $\mathbf{P}$ & Irreg. & $120 \times 1500$ & $0-120$ & 1.5 & $200 \mathrm{C} / 200 \mathrm{~h}$ preaged. Interconnected porosity. \\
\hline $339 / \mathrm{Kao} / 15$ & 200 & C111392-123-4 & 9 & $10 \mathrm{M}+$ & Runout & - & - & - & $\begin{array}{c}\text { Im-meas- } \\
\text { urable }\end{array}$ & $\begin{array}{l}200 \mathrm{C} / 200 \mathrm{~h} \text { preaged. Cracks detected on surface } \\
\text { shots and fibers. Out for Synchrtron Rad. CAT. by } \\
\text { Tom Breunig-Sandia Lab }\end{array}$ \\
\hline $339 / \mathrm{KaO} / 15$ & 200 & C111392-130-2 & 9 & $10 \mathrm{M}+$ & $\begin{array}{c}\text { Runout } \\
S\end{array}$ & Spher. & 100 & 0 & 1 & $\begin{array}{l}\text { 200C/200h preaged. CAT scanned. Pulled to fail. at } \\
\text { RT after fatigue testing; UTS }=29.4 \mathrm{ksi} \text {. Unaged. }\end{array}$ \\
\hline & & & & & & & & & & \\
\hline & & & & & & & & & & \\
\hline & & & & & & & & & & \\
\hline
\end{tabular}




\begin{tabular}{|c|c|c|c|c|c|c|c|c|c|c|}
\hline Material & $\begin{array}{c}\text { Temp } \\
(\mathrm{OC})\end{array}$ & $\begin{array}{l}\text { Sample } \\
\text { ID \& \# }\end{array}$ & $\begin{array}{l}\text { Stress } \\
\text { (ksi) }\end{array}$ & \#Cycles & $\begin{array}{l}\text { Initiation } \\
\text { Site }\end{array}$ & $\begin{array}{l}\text { Defect } \\
\text { Shape }\end{array}$ & $\mid \begin{array}{c}\text { Defect Size } \\
\mathrm{XxY}(\mu \mathrm{m})\end{array}$ & $\begin{array}{c}\text { Defect } \\
\text { Depth } \\
\text { (um) }\end{array}$ & $\begin{array}{c}\text { Fatigue } \\
\text { Zone Size } \\
(\mathrm{mm})\end{array}$ & Comments \\
\hline & & & & \multicolumn{5}{|c|}{ 15\% KaOWOOl/LOW ShOt } & & \\
\hline $339 / \mathrm{Kaa} / 15$ & 300 & C051194-29-2 & 14 & $4.95 E+03$ & & & & & & Aged $300 \mathrm{C} / 200 \mathrm{hr}$. New batch. \\
\hline $339 / \mathrm{Kao} / 15$ & 300 & C051194-25-3 & 14 & $6.42 \mathrm{E}+03$ & & & & & & Aged $300 \mathrm{C} / 200 \mathrm{hr}$. New batch. \\
\hline $339 / \mathrm{Kao} / 15$ & 300 & C051194-17-3 & 14 & $2.35 E+04$ & $\mathrm{~S}$ & Irreg. & $75 \times 20$ & $0-20$ & 1 & $\begin{array}{l}\text { Unaged. New batch. Preform macro-crack on shlder } \\
\text { \& gage. Solid shot. }\end{array}$ \\
\hline $339 / \mathrm{Kao} / 15$ & 300 & C051194-17-6 & 12 & $1.13 E+05$ & $S$ & Spher. & 25 & 80 & 1 & $\begin{array}{l}\text { Unaged. New batch. Preform crack on shlder \& gage. } \\
\text { Solid shot. }\end{array}$ \\
\hline $339 / \mathrm{Kaa} / 15$ & 300 & C051194-27-3 & 12 & $1.12 \mathrm{E}+05$ & $\mathrm{~S}$ & Spher. & 40 & 0 & 1.2 & Unaged. New batch. Solid shot. \\
\hline $339 / \mathrm{Kao} / 15$ & 300 & C051194-23-2 & 12 & $4.21 E+04$ & $\mathrm{~S}$ & Spher. & 60 & $0-70$ & 1 & Unaged. 3rd batch. Hollow shot. \\
\hline $339 / \mathrm{KaO} / 15$ & 300 & C051194-23-3 & 12 & $3.20 \mathrm{E}+04$ & S & Oval & $55 \times 65$ & $0-55$ & 1 & $\begin{array}{l}\text { Preaged } 300 \mathrm{C} / 200 \mathrm{hr} \text {. 3rd batch. Hollow shot filled } \\
\text { w/matrix. }\end{array}$ \\
\hline $339 / \mathrm{Kao} / 15$ & 300 & C051194-27-4 & 11 & $7.59 \mathrm{E}+04$ & $\mathbf{S}$ & Spher. & 65 & 3 & 1.2 & $\begin{array}{l}\text { Unaged. New batch. Preform macro-crack on shlder. } \\
\text { Solid shot. }\end{array}$ \\
\hline $339 / \mathrm{Kao} / 15$ & 300 & C051194-29-1 & 11 & $4.94 \mathrm{E}+04$ & & & & & & Aged 300C/200hr. New batch. \\
\hline $339 / \mathrm{Kaa} / 15$ & 300 & C051194-15-2 & 10 & $1.22 E+06$ & $S$ & Peach & $81 \times 72$ & $3.0-75$ & 1.5 & $\begin{array}{l}\text { Preaged } 300 \mathrm{C} / 200 \mathrm{hr} \text {. 3rd batch. Solid shot. Tester } \\
\text { untripped on fail. Retest recommended. }\end{array}$ \\
\hline $339 / \mathrm{Kao} / 15$ & 300 & C051194-27-5 & 10 & $1.15 \mathrm{E}+06$ & Fiber & Fiber & $50 \times 10$ & $0-10$ & 1.3 & $\begin{array}{l}\text { Unaged. New batch. Preform crack on shoulder. Fiber } \\
\text { doublet. }\end{array}$ \\
\hline $339 / \mathrm{KaO} / 15$ & 300 & C051194-32-3 & 10 & $1.12 E+06$ & $\mathrm{~S}$ & Spher. & 15 & 15 & 0.86 & $\begin{array}{l}\text { Unaged. Small shots cluster. Cluster } 30 \mu \mathrm{m} \text { size \& } 0 \\
\text { depth. }\end{array}$ \\
\hline $339 / \mathrm{Kao} / 15$ & 300 & C051194-15-5 & 10 & $2.57 \mathrm{E}+05$ & $\mathrm{~s}$ & Irreg. & $60 \times 180$ & $0-80$ & 1.25 & Unaged. 3rd batch. Shot surface $x$-section $\sim 70 \mu \mathrm{m}$. \\
\hline $339 / \mathrm{KaO} / 15$ & 300 & C051194-22-4 & 9.5 & $2.68 \mathrm{E}+05$ & $\mathrm{~S}$ & Irreg, & $70 \times 60$ & $0-60$ & 1.6 & Unaged. \\
\hline $339 / \mathrm{Kao} / 15$ & 300 & C051194-32-6 & 9 & $3.00 \mathrm{E}+06$ & S \& Fiber & Irreg. & 30 & $3.0-30$ & 1.5 & Unaged. Cluster of small shots \& fibers. \\
\hline $339 / \mathrm{Kao} / 15$ & 300 & C051194-27-6 & 9 & $1.53 \mathrm{E}+06$ & $\mathrm{~S}$ & $\begin{array}{l}\text { Irreg. } \\
\text { Cluster }\end{array}$ & $\begin{array}{l}50 \times 70 \\
50 \times 50\end{array}$ & $0-50$ & 1.25 & $\begin{array}{l}\text { Unaged. New batch. Pre-form crack on shoulder \& } \\
\text { gage. }\end{array}$ \\
\hline $339 / \mathrm{KaO} / 15$ & 300 & $\operatorname{co5} 1194-25-1$ & 9 & $6.02 E+05$ & & & & & & $300 \mathrm{C} / 200 \mathrm{hr}$ \\
\hline $339 / \mathrm{Kao} / 15$ & 300 & C051094-25-2 & 9 & $3.32 E+05$ & $\begin{array}{c}\text { Powder } \\
\text { cluster \& } \\
\text { I(R) }\end{array}$ & $\begin{array}{l}\text { Irreg. \& } \\
\text { Rod }\end{array}$ & $\begin{array}{c}400 \times 200 \\
90 \times 15 \\
\end{array}$ & $\begin{array}{c}0-200 \\
0-80\end{array}$ & & $300 \mathrm{C} / 200 \mathrm{hr}$ \\
\hline $339 / \mathrm{Koa} / 15$ & 300 & C051194-21-2 & 8.5 & $4.26 \mathrm{E}+06$ & I? & Irreg. & $20 \times 20$ & 0 & 2 & Unaged. \\
\hline $339 / \mathrm{Koa} / 15$ & 300 & C051194-32-5 & 8.5 & $3.40 \mathrm{E}+06$ & lor $S$ & Irreg. & $10 \times 30$ & 4 & 2 & Unaged. \\
\hline
\end{tabular}




\begin{tabular}{|c|c|c|c|c|c|c|c|c|c|c|}
\hline Material & $\begin{array}{c}\text { Temp } \\
(\mathrm{OC})\end{array}$ & $\begin{array}{l}\text { Sample } \\
\text { ID \& \# }\end{array}$ & $\begin{array}{c}\text { Stress } \\
(\mathrm{ksi})\end{array}$ & \#Cycles & $\begin{array}{l}\text { Initiation } \\
\text { Site }\end{array}$ & $\begin{array}{l}\text { Defect } \\
\text { Shape }\end{array}$ & $\begin{array}{c}\text { Defect Size } \\
X \times Y(\mu \mathrm{m})\end{array}$ & $\begin{array}{c}\text { Defect } \\
\text { Depth } \\
(\mu \mathrm{m})\end{array}$ & $\begin{array}{c}\text { Fatigue } \\
\text { Zone Size } \\
(\mathrm{mm})\end{array}$ & Comments \\
\hline $339 / \mathrm{KaO} / 15$ & 300 & C051194-21-5 & 8 & $8.36 \mathrm{E}+06$ & Unid'ble & $N / A$ & N/A & N/A & 2.1 & Unaged. \\
\hline $339 / \mathrm{Kao} / 15$ & 300 & C051194-16-2 & 8 & $8.24 \mathrm{E}+06$ & $\mathrm{~S}$ & Irreg. & 18-Dec & $35-50$ & 1.6 & Unaged. 3rd batch. Preform crack on shldr \& gage. \\
\hline $339 / \mathrm{Kao} / 15$ & 300 & C051194-22-1 & 8 & $7.82 \mathrm{E}+06$ & $S$ & Spher. & $20 \times 10$ & 10 & 2.5 & Unaged. \\
\hline $339 / \mathrm{Kao} / 15$ & 300 & C051194-16-4 & 8 & $2.45 \mathrm{E}+06$ & Unid'ble & $\mathrm{N} / \mathrm{A}$ & N/A & $N / A$ & N/A & $\begin{array}{l}\text { Preaged } 300 \mathrm{C} / 200 \mathrm{hr} .3 \mathrm{rd} \text { batch. Test interrupted } \\
@ 1.65 \mathrm{MC} \text { cycles . }\end{array}$ \\
\hline $339 / \mathrm{Kao} / 15$ & 300 & C051194-32-1 & 7.5 & $\begin{array}{l}\text { 10MC } \\
\text { Runout }\end{array}$ & N/A & N/A & N/A & N/A & N/A & $\begin{array}{l}\text { Unaged. Out for Syncrton. Rad. CAT by Tom Breunig- } \\
\text { Sandia. Lab. }\end{array}$ \\
\hline $339 / \mathrm{Koa} / 15$ & 300 & C051194-21-4 & 7.5 & $6.32 \mathrm{E}+06$ & $\begin{array}{l}S \\
S\end{array}$ & $\begin{array}{l}\text { Spher. } \\
\text { Spher. }\end{array}$ & $\begin{array}{c}80 \times 10 \\
15\end{array}$ & $\begin{array}{l}60 \\
25\end{array}$ & 2.6 & Unaged. 3 small shots, separate but adjacent. \\
\hline $339 / \mathrm{KaO} / 15$ & 300 & C051194-29-4 & 7 & $\begin{array}{l}\text { 10MC } \\
\text { Runout }\end{array}$ & & & & & & Preaged $300 \mathrm{C} / 200 \mathrm{hr}$. \\
\hline & & & & & & & & & & \\
\hline $339 / \mathrm{KaO} / 15$ & 200 & C051194-27-1 & 17 & $4.59 \mathrm{E}+04$ & $S$ & Spher. & 80 & 0 & 1 & $\begin{array}{l}\text { Unaged. New batch from WB. Partly solid shot filled } \\
\text { w/matrix. }\end{array}$ \\
\hline $339 / \mathrm{KaO} / 15$ & 200 & C051194-17-5 & 16 & $8.33 E+04$ & $S$ & Oval & $110 \times 35$ & 0 & 1 & $\begin{array}{l}\text { Unaged. New batch. Preform crack on shlder \& gage. } \\
\text { Solid shot. }\end{array}$ \\
\hline $339 / \mathrm{KaO} / 15$ & 200 & C051194-15-3 & 16 & $2.52 E+04$ & $S$ & Irreg. & $58 \times 68$ & $15-84$ & 1.2 & Preaged $200 \mathrm{C} / 200 \mathrm{hr}$. 3rd batch. Hollow shot. \\
\hline $339 / \mathrm{KaO} / 15$ & 200 & C051194-16-3 & 16 & $5.49 \mathrm{E}+03$ & 1 & $\begin{array}{l}\text { Hemi- } \\
\text { sph. }\end{array}$ & $200 \times 100$ & $0-100$ & 1 & $\begin{array}{l}\text { Preaged } 200 \mathrm{C} / 200 \mathrm{hr} \text {. 3rd batch. Inclusion and fine- } \\
\text { grained mat } x \text { area. Probably thinskinned shot. }\end{array}$ \\
\hline $339 / \mathrm{KaO} / 15$ & 200 & C051194-21-3 & 15 & $2.05 \mathrm{E}+05$ & $S$ & Irreg. & $85 \times 50$ & $0-50$ & 1.2 & Unaged.Spherical shot with tail. \\
\hline $339 / \mathrm{KaO} / 15$ & 200 & C051194-17-4 & 14 & $1.13 E+06$ & $S$ & Irreg. & $50 \times 90$ & $0-90$ & 1 & $\begin{array}{l}\text { Unaged. New batch. Preform crack on shoulder. Solid } \\
\text { shot. }\end{array}$ \\
\hline $339 / \mathrm{KaO} / 15$ & 200 & C051194-22-2 & 14 & $5.14 E+05$ & $S$ & Spher. & $100 \times 50$ & $0-50$ & 1.4 & Unaged. Half-solid, half filled w/ fragments. \\
\hline $339 / \mathrm{KaO} / 15$ & 200 & C051194-23-6 & 14 & $1.36 \mathrm{E}+05$ & $S$ & Spher. & 65 & $0-65$ & 1 & $\begin{array}{l}\text { Preaged } 200 \mathrm{C} / 200 \mathrm{hr} \text {. 3rd batch. Hollow w/2 } \mu \text { wall } \\
\text { thickness. }\end{array}$ \\
\hline $339 / \mathrm{KaO} / 15$ & 200 & C051194-23-4 & 14 & $1.22 E+05$ & $S$ & Gourd & $52 \times 80$ & $0-70$ & 1.25 & Preaged $200 \mathrm{C} / 200 \mathrm{hr}$. 3rd batch. \\
\hline $339 / \mathrm{Koa} / 15$ & 200 & C051194-32-2 & 13 & $1.87 \mathrm{E}+06$ & $S$ & Irreg. & $30 \times 30$ & 6 & 1.6 & $\begin{array}{l}\text { Unaged. Chain (Elliptic, } 130 \times 180 \text { ) of shots ( } 5 \text { to } 10 \times \\
20 \text { to } 60 \mu \mathrm{m}) \text {. }\end{array}$ \\
\hline $339 / \mathrm{KaO} / 15$ & 200 & C051194-22-3 & 13 & $8.44 \mathrm{E}+05$ & $\mathrm{~S}$ & Elliptic & $50 \times 60$ & 0 & 1.6 & Unaged. Same. Partly hollow shot. \\
\hline $339 / \mathrm{KaO} / 15$ & 200 & C051194-21-1 & 12 & $6.04 \mathrm{E}+06$ & $\mathrm{~S}$ & Elliptic & $6 \times 15$ & 10 & 1.25 & Unaged. Same. \\
\hline $339 / \mathrm{Kao} / 15$ & 200 & C051194-22-5 & 12 & $9.08 \mathrm{E}+06$ & $\mathrm{~S}$ & Spher. & 50 & 5 & 1.75 & Unaged. Same. Partly hollow shot. \\
\hline $339 / \mathrm{Kao} / 15$ & 200 & $\operatorname{co51194-27-2}$ & 12 & $1.66 \mathrm{E}+06$ & $n / a$ & $n / a$ & $n / a$ & $\mathrm{n} / \mathrm{a}$ & $n / a$ & $\begin{array}{l}\text { Unaged. New from WB. Pre-form crack on shoulder \& } \\
\text { gage. }\end{array}$ \\
\hline $339 / \mathrm{Kao} / 15$ & 200 & C051194-15-1 & 12 & $1.22 E+06$ & $S$ & Irreg. & $60 \times 55$ & Feb-57 & 1.5 & Preaged $200 \mathrm{C} / 200 \mathrm{hr}$. 3rd batch. Solid shot. \\
\hline
\end{tabular}




\begin{tabular}{|c|c|c|c|c|c|c|c|c|c|c|}
\hline Material & $\begin{array}{c}\text { Temp } \\
(\mathrm{OC})\end{array}$ & $\begin{array}{l}\text { Sample } \\
\text { ID \& \# }\end{array}$ & $\begin{array}{c}\text { Stress } \\
(\mathrm{ksi})\end{array}$ & \#Cycles & $\begin{array}{l}\text { Initiation } \\
\text { Site }\end{array}$ & $\begin{array}{l}\text { Defect } \\
\text { Shape }\end{array}$ & $\begin{array}{c}\text { Defect Size } \\
X \times Y(\mu \mathrm{m})\end{array}$ & $\begin{array}{c}\text { Defect } \\
\text { Depth } \\
(\mu \mathrm{m})\end{array}$ & $\begin{array}{c}\text { Fatigue } \\
\begin{array}{c}\text { Zone Size } \\
(\mathrm{mm})\end{array}\end{array}$ & Comments \\
\hline $339 / \mathrm{Kao} / 15$ & 200 & C051194-16-5 & 12 & $8.10 E+05$ & $\mathrm{~S}$ & Irreg. & $50 \times 70$ & $0-70$ & & Preaged $200 \mathrm{C} / 200 \mathrm{hr}$. 3rd batch. Hollow filled. \\
\hline $339 / \mathrm{Kao} / 15$ & 100 & C051194-25-4 & 14 & $4.20 \mathrm{E}+04$ & & & & & & Aged $300 \mathrm{C} / 200 \mathrm{hr}$. New batch. \\
\hline $339 / \mathrm{KaO} / 15$ & 100 & C051194-29-3 & 14 & $3.83 E+04$ & & & & & & Aged $300 \mathrm{C} / 200 \mathrm{hr}$. New batch. \\
\hline $339 / \mathrm{kao} / 15$ & 25 & C051194-15-6 & 18 & $2.81 E+05$ & $\mathrm{~S}$ & Irreg. & $55 \times 120$ & $0-120$ & 1.2 & Unaged. 3rd batch. \\
\hline $339 / \mathrm{Kao} / 15$ & 25 & C051194-17-2 & 18 & $1.44 E+05$ & $S$ & Irreg. & $70 \times 25$ & $0-50$ & 1 & $\begin{array}{l}\text { Unaged.New batch. Preform crack on shlder \& gage. } \\
\text { Solid shot. Thick fibers nearby. }\end{array}$ \\
\hline $339 / \mathrm{Kao} / 15$ & 25 & C051194-23-5 & 17 & $2.29 \mathrm{E}+06$ & $\mathrm{~S}$ & Irre.. & $50 \times 66$ & $0-66$ & 1 & Unaged. 3rd batch. Many fibers nearby. \\
\hline $339 / \mathrm{Kao} / 15$ & 25 & C051194-17-1 & 17 & $1.44 \mathrm{E}+05$ & S & Irreg. & $20 \times 130$ & $0-90$ & 1.1 & $\begin{array}{l}\text { Unaged. New batch. Preform crack on shoulder \& } \\
\text { gage. Fiber-like shot. Same length fiber nearby. }\end{array}$ \\
\hline $339 / \mathrm{KaO} / 15$ & 25 & C051194-16-1 & 17 & $1.40 \mathrm{E}+05$ & $\mathrm{~S}$ & Spher. & $65 \times 50$ & $0-50$ & 1.2 & 3rd batch. Unaged. \\
\hline $339 / \mathrm{KaO} / 15$ & 25 & C051194-32-4 & 17 & $1.34 \mathrm{E}+05$ & $\mathrm{~S}$ & Irreg. & $100 \times 150$ & $0-150$ & 1 & Unaged. \\
\hline $339 / \mathrm{KaO} / 15$ & 25 & C051194-21-6 & 16 & $1.39 \mathrm{E}+07$ & Runout & & & & & Unaged. \\
\hline $339 / \mathrm{Kao} / 15$ & 25 & C051194-15-4 & 16 & $9.30 \mathrm{E}+04$ & $\mathrm{~S}$ & Spher. & $80 \times 100$ & $0-80$ & 1.25 & Unaged. 3rd batch. Preform crack on gage \& shlder. \\
\hline $339 / \mathrm{KaO} / 15$ & 25 & C051194-23-1 & 16 & $8.98 \mathrm{E}+04$ & Fiber & Elong. & $200 \times 12$ & $0-45$ & 1.2 & Unaged. \\
\hline & & & & & & & & & & \\
\hline & & & & & & & & & & \\
\hline & & & & & & & & & & \\
\hline & & & & & & & & & & \\
\hline & & & & & & & & & & \\
\hline & & & & & & & & & & \\
\hline & & & & & & & & & & \\
\hline & & & & & & & & & & \\
\hline & & & & & & & & & & \\
\hline & & & & & & & & & & \\
\hline & & & & & & & & & & \\
\hline & & & & & & & & & & \\
\hline & & & & & & & & & & \\
\hline
\end{tabular}




\begin{tabular}{|c|c|c|c|c|c|c|c|c|c|c|}
\hline Material & $\begin{array}{c}\text { Temp } \\
(\mathrm{OC})\end{array}$ & $\begin{array}{l}\text { Sample } \\
\text { ID \& \# }\end{array}$ & $\begin{array}{c}\text { Stress } \\
(\mathrm{ksi})\end{array}$ & \#Cycles & $\begin{array}{l}\text { Initiation } \\
\text { Site }\end{array}$ & $\begin{array}{l}\text { Defect } \\
\text { Shape }\end{array}$ & $\begin{array}{c}\text { Defect Size } \\
X \times Y(\mu \mathrm{m})\end{array}$ & $\begin{array}{c}\text { Defect } \\
\text { Depth } \\
(\mu \mathrm{m})\end{array}$ & $\begin{array}{c}\text { Fatigue } \\
\begin{array}{c}\text { Zone Size } \\
(\mathrm{mm})\end{array}\end{array}$ & Comments \\
\hline & & & & \multicolumn{5}{|c|}{ 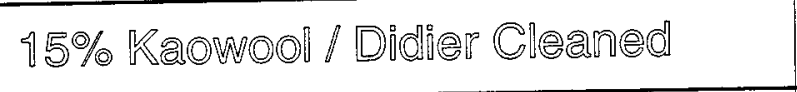 } & & \\
\hline $339 / \mathrm{Kao} / 15$ & 300 & C051094-45-3 & 11 & $9.00 E+04$ & $\begin{array}{l}\text { Powder } \\
\text { Cluster }\end{array}$ & Oval & $45 \times 27$ & $0-27$ & & $\begin{array}{l}300 \mathrm{C} / 200 \mathrm{hr} \text {. Pouch of of un-sintered particles \& } \\
\text { partially glazed } 3 \text { layer skin, upto } 10 \mu \mathrm{m} \text { thick. }\end{array}$ \\
\hline $339 / \mathrm{Kao} / 15$ & 300 & C051094-44-2 & 10 & $2.85 E+05$ & I \& Fiber & $\begin{array}{l}\text { Oval } \\
\text { fiber }\end{array}$ & $\begin{array}{l}15 \times 10 \\
100 \times 6 \\
\end{array}$ & $\begin{array}{c}65-75 \\
120-190 \\
\end{array}$ & & $\begin{array}{l}300 \mathrm{C} / 200 \mathrm{hr} \text {. Source area abundant w/other small } \\
\text { defects. }\end{array}$ \\
\hline $339 / \mathrm{KaO} / 15$ & 300 & C051094-42-1 & 10 & $3.20 \mathrm{E}+05$ & 1 & Irreg. & $55 \times 28$ & $0-28$ & & $300 \mathrm{C} / 200 \mathrm{hr}$. Solid incl'sn. \\
\hline $339 / \mathrm{KaO} / 15$ & 300 & C051094-49-1 & 9 & $1.01 E+06$ & I & Potato & $100 \times 42$ & 3500 & 2 & $\begin{array}{l}300 \mathrm{C} / 200 \mathrm{hr} . \text { Incls'n near the center. Incl's'sn } \\
\text { w/intemal cracks. }\end{array}$ \\
\hline & & & & & & & & & & \\
\hline $339 / \mathrm{Kao} / 15$ & 300 & C051094-59-06 & $1.7-17$ & $2.43 \mathrm{E}+03$ & & & & & & $300 \mathrm{C} / 200 \mathrm{hr} . \quad R=0.1$ \\
\hline $339 / \mathrm{Kao} / 15$ & 300 & C051094-58-3 & $1.2-12$ & $9.61 \mathrm{E}+05$ & & & & & & $300 \mathrm{C} / 200 \mathrm{hr} . \quad R=0.1$ \\
\hline & & & & & & & & & & \\
\hline $339 / \mathrm{Kao} / 15$ & 275 & C051094-48-5 & 13 & $1.40 E+04$ & $\mathrm{R}$ & Fiber & $20 \times 85$ & $0-65$ & & $300 \mathrm{C} / 200 \mathrm{hr}$. Surf dim. $50 \mu$ \\
\hline $339 / \mathrm{Kao} / 15$ & 250 & C051094-48-3 & 13 & $5.38 \mathrm{E}+04$ & $\mathrm{R}$ & Fiber & & & & $\begin{array}{l}300 \mathrm{C} / 200 \mathrm{hr} \text {. Source area abundant w/small shots(?) \& } \\
\text { fibers. }\end{array}$ \\
\hline $339 / \mathrm{Kao} / 15$ & 225 & C051094-47-2 & 13 & $3.60 \mathrm{E}+04$ & $\mathrm{R}$ & 5-gon & $110-70$ & 550 & & $300 \mathrm{C} / 200 \mathrm{hr}$. Huge subsurf. Defect. \\
\hline $339 / \mathrm{Kao} / 15$ & 225 & C051094-49-2 & 13 & $4.33 E+04$ & $\mathbf{R}$ & $\begin{array}{c}\text { Equiaxe } \\
\mathrm{d}\end{array}$ & $15 \times 15$ & $10.0-25$ & & $300 \mathrm{C} / 200 \mathrm{hr}$ \\
\hline $339 / \mathrm{KaO} / 15$ & 200 & C051094-47-5 & 16 & $2.23 E+04$ & $\mathrm{R}$ & Elong. & $60-16$ & $0-25$ & & $200 \mathrm{C} / 200 \mathrm{hr} .2 / /$ long shots. Surface dim's'n $50 \mu \mathrm{m}$. \\
\hline $339 / \mathrm{Kao} / 15$ & 200 & C051094-49-3 & 15 & $5.11 \mathrm{E}+04$ & $\mathrm{R}$ & Fiber & $150 \times 20$ & $0-30$ & & 200C/200hr. Defect surf.exposed $-0-$ \\
\hline $339 / \mathrm{KaO} / 15$ & 200 & C051094-49-5 & 14 & $1.64 \mathrm{E}+05$ & $\mathrm{R}$ & Fiber & $105 \times 6$ & $0-8$ & & $200 \mathrm{C} / 200 \mathrm{hr}$. Surf dim. $45 \mu$ \\
\hline $339 / \mathrm{Kao} / 15$ & 200 & C051094-48-1 & 13 & $3.57 E+05$ & $\mathrm{R}$ & Elong. & $90-30$ & $0-75$ & & $200 \mathrm{C} / 200 \mathrm{hr}$. Long tapered. Surface dimesion $70 \mu \mathrm{m}$. \\
\hline $339 / \mathrm{Kao} / 15$ & 200 & C051094-48-2 & 12 & $9.80 \mathrm{E}+05$ & $\begin{array}{l}\text { Powder } \\
\text { cluster }\end{array}$ & $\mathrm{Egg}$ & $55 \times 30$ & $0-50$ & & $\begin{array}{l}\text { 200C/200hr. Incompletely sintered powder cluster. } \\
\text { Surf dim } 15 \mu \mathrm{m} \text {. }\end{array}$ \\
\hline $339 / \mathrm{Kao} / 15$ & 200 & C051094-47-4 & 11 & $5.78 \mathrm{E}+06$ & $\mathrm{R}$ or $\mathrm{I}$ & Spher. & $50 \times 37$ & $0-37$ & & $200 \mathrm{C} / 200 \mathrm{hr}$. Solid. Multi-fracture. Surf $\operatorname{dim} 50 \mu \mathrm{m}$. \\
\hline & & & & & & & & & & \\
\hline $339 / \mathrm{Kao} / 15$ & 200 & C051094-59-3 & 15 & $1.27 E+04$ & & & & & & $250 \mathrm{C} / 200 \mathrm{hr}$. \\
\hline $339 / \mathrm{Kao} / 15$ & 200 & C051094-59-1 & 13 & $1.09 \mathrm{E}+05$ & & & & & & $250 \mathrm{C} / 200 \mathrm{hr}$ \\
\hline
\end{tabular}




\begin{tabular}{|c|c|c|c|c|c|c|c|c|c|c|}
\hline Material & $\begin{array}{l}\text { Temp } \\
\text { (oC) }\end{array}$ & $\begin{array}{l}\text { Sample } \\
\text { ID \&\# }\end{array}$ & $\begin{array}{c}\text { Stress } \\
(\mathrm{ksi})\end{array}$ & \#Cycles & $\begin{array}{l}\text { Initiation } \\
\text { Site }\end{array}$ & $\begin{array}{l}\text { Defect } \\
\text { Shape }\end{array}$ & $\begin{array}{c}\text { Defect Size } \\
X x Y(\mu \mathrm{m})\end{array}$ & $\begin{array}{l}\text { Defect } \\
\text { Depth } \\
(\mu \mathrm{m})\end{array}$ & \begin{tabular}{|c|} 
Fatigue \\
Zone Size \\
$(\mathrm{mm})$
\end{tabular} & Comments \\
\hline $339 / \mathrm{KaO} / 15$ & 200 & C051094-59-5 & 11 & $7.06 \mathrm{E}+05$ & & & & & & $250 / 200 h r$. \\
\hline & & & & & & & & & & \\
\hline $339 / \mathrm{KaO} / 15$ & 200 & C051094-45-2 & 12 & $1.26 \mathrm{E}+05$ & $\mathrm{R}$ & Elong. & $105 \times 23$ & $0-30$ & & $300 \mathrm{C} / 200 \mathrm{hr}$. Long elongated shot. \\
\hline 339/Kao/15 & 200 & C051094-44-1 & 11 & $3.79 \mathrm{E}+05$ & $\begin{array}{l}\text { Powder } \\
\text { cluster }\end{array}$ & Irreg. & $40 \times 30$ & $10.0-50$ & & $300 \mathrm{C} / 200 \mathrm{hr}$. Pocket of incomplete sinter. \\
\hline $339 / \mathrm{Kao} / 15$ & 200 & C051094-44-3 & 10 & $1.33 \mathrm{E}+06$ & $\mathrm{R}$ & Fiber & $85 \times 3$ & $0-60$ & & $300 \mathrm{C} / 200 \mathrm{hr}$. Init. area abundant w/other fibers \& incl's. \\
\hline $339 / \mathrm{KaO} / 15$ & 200 & C051094-42-3 & 10 & $8.79 \mathrm{E}+05$ & 1 & Irreg. & $25 \times 15$ & $0-15$ & & $300 \mathrm{C} / 200 \mathrm{hr}$. Fibers \& a larger incls'n nearby. \\
\hline $339 / \mathrm{Kao} / 15$ & 175 & C051094-49-4 & 13 & $8.45 \mathrm{E}+05$ & $\mathrm{R}$ or $\mathrm{I}$ & Elliptic & $110-60$ & Center & & $200 \mathrm{C} / 200 \mathrm{hr}$. Multiple fract. \\
\hline $339 / \mathrm{KaO} / 15$ & 150 & C051094-47-3 & 13 & $8.15 \mathrm{E}+04$ & $\mathrm{R}$ & Flake & $110-20$ & $130-150$ & & $300 \mathrm{C} / 200 \mathrm{hr}$ \\
\hline $339 / \mathrm{KaO} / 15$ & 125 & C051094-47-1 & 13 & $5.26 \mathrm{E}+04$ & $\mathrm{R}$ & Elong. & $90 \times 17$ & $0-30$ & & $300 \mathrm{C} / 200 \mathrm{hr}$. Surf dim $50 \mu \mathrm{m}$. \\
\hline $339 / \mathrm{Kao} / 15$ & 100 & C051094-48-4 & 13 & $1.18 \mathrm{E}+05$ & $R$ & Elong. & $80-20$ & $0-30$ & & $300 \mathrm{C} / 200 \mathrm{hr}$. Surf dim $25 \mu \mathrm{m}$. \\
\hline $339 / \mathrm{KaO} / 15$ & 100 & C051094-58-4 & $1.2-12$ & $\begin{array}{c}10 \mathrm{M}+ \\
\text { runout }\end{array}$ & & & & & & $300 \mathrm{C} / 200 \mathrm{hr} . \quad R=0.1$ \\
\hline $339 / \mathrm{Kao} / 15$ & 100 & C051094-42-4 & 12 & $2.29 \mathrm{E}+05$ & $\mathrm{R}$ & Elong. & & & & $300 \mathrm{C} / 200 \mathrm{hr}$. Source area rich w/ small shots \& fibers. \\
\hline 339/Kao/15 & 100 & C051094-45-4 & 11 & $1.01 E+06$ & 1 & Irreg. & $55 \times 15$ & $0-15$ & & $300 \mathrm{C} / 200 \mathrm{hr}$. Large incl. @ source and fibers nearby. \\
\hline $339 / \mathrm{Kao} / 15$ & 100 & C051094-42-2 & 10 & $\begin{array}{c}9.7 E+06 \\
\text { Runout }\end{array}$ & & & & & & 300C/200hr. Stopped @9.7MC. \\
\hline $339 / \mathrm{kao} / 15$ & 100 & C051094-44-4 & 10 & $\begin{array}{l}10 \mathrm{MC}+ \\
\text { Runout }\end{array}$ & & & & & & $300 \mathrm{C} / 200 \mathrm{hr}$. \\
\hline & & & & & \multicolumn{3}{|c|}{ R: Reinforrcement material. } & & & \\
\hline
\end{tabular}




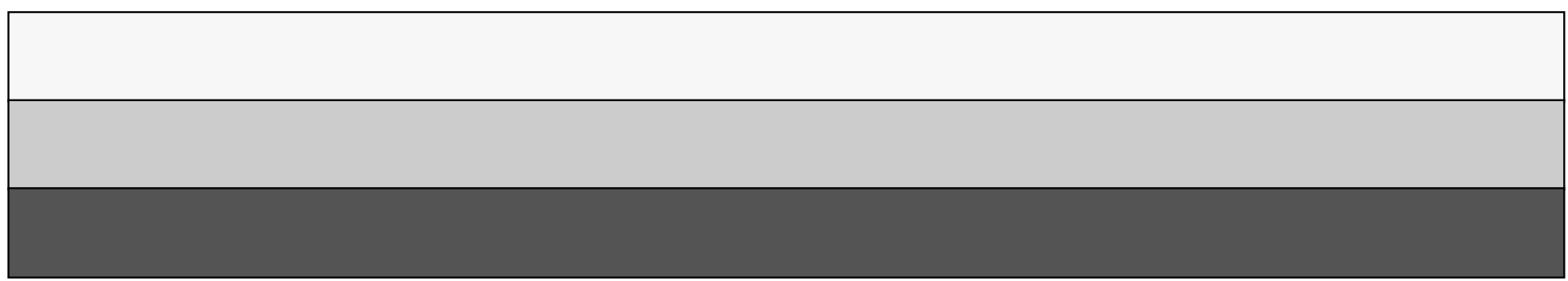

